\title{
Determining the impacts of high traffic roads on painted turtle (Chrysemys picta marginata) populations in eastern Ontario
}

\section{By}

\begin{abstract}
Alexandra Dorland
A thesis submitted to the Faculty of Graduate and Postdoctoral Affairs in partial fulfillment of the requirements for the degree of

\author{
Master of Science \\ in \\ Biology \\ Carleton University \\ Ottawa, Ontario \\ May, 2012
}

(C) 2012, Alexandra Dorland 
Library and Archives

Canada

Published Heritage

Branch

395 Wellington Street

Ottawa ON K1A ON4

Canada
Bibliothèque et

Archives Canada

Direction du

Patrimoine de l'édition

395 , rue Wellington

Ottawa ON K1A ON4

Canada
Your file Votre référence

ISBN: 978-0-494-91551-6

Our file Notre référence

ISBN: $978-0-494-91551-6$
NOTICE:

The author has granted a nonexclusive license allowing Library and Archives Canada to reproduce, publish, archive, preserve, conserve, communicate to the public by telecommunication or on the Internet, loan, distrbute and sell theses worldwide, for commercial or noncommercial purposes, in microform, paper, electronic and/or any other formats.

The author retains copyright ownership and moral rights in this thesis. Neither the thesis nor substantial extracts from it may be printed or otherwise reproduced without the author's permission.
AVIS:

L'auteur a accordé une licence non exclusive permettant à la Bibliothèque et Archives Canada de reproduire, publier, archiver, sauvegarder, conserver, transmettre au public par télécommunication ou par l'Internet, prêter, distribuer et vendre des thèses partout dans le monde, à des fins commerciales ou autres, sur support microforme, papier, électronique et/ou autres formats.

L'auteur conserve la propriété du droit d'auteur et des droits moraux qui protege cette thèse. $\mathrm{Ni}$ la thèse ni des extraits substantiels de celle-ci ne doivent être imprimés ou autrement reproduits sans son autorisation.
In compliance with the Canadian Privacy Act some supporting forms may have been removed from this thesis.

While these forms may be included in the document page count, their removal does not represent any loss of content from the thesis.
Conformément à la loi canadienne sur la protection de la vie privée, quelques formulaires secondaires ont été enlevés de cette thèse.

Bien que ces formulaires aient inclus dans la pagination, il n'y aura aucun contenu manquant. 


\begin{abstract}
Road mortality is thought to be a leading cause of turtle population decline. Empirical evidence is lacking however, thus the purpose of this study was to test the prediction that road mortality reduces turtle populations. While controlling for potentially confounding variables, I compared relative abundance of painted turtles (Chrysemys picta marginata) in 20 ponds across eastern Ontario, 10 very close to high traffic roads and 10 as far as possible from any major roads. I did not find a significant effect of roads on turtle relative abundance, suggesting that road mortality does not negatively affect the sampled turtle populations. I suggest that other factors may reduce or counter-balance the negative effects of road mortality. There are however, circumstances in which road mortality poses a distinct threat to turtle population persistence because of forced over-land migration across high traffic roads. It is at such sites that mitigation efforts for painted turtles should be focussed.
\end{abstract}




\section{Acknowledgements}

First and foremost I would like to thank my supervisor, Dr. Lenore Fahrig, for not only providing me with this wonderful opportunity, but also providing guidance and many helpful comments during the planning, analysis and writing process. I imagine that it cannot be easy with so many students depending on you, but the dedication and care you manage to show to each of us is truly appreciated.

Thank you to the members of my advisory committee, Dr. Gabriel BlouinDemers, Dr. Charles Francis and Dr. Adam Smith, for all of your useful feedback during our meetings.

I would also like to thank all the members of the Geomatics and Landscape Ecology Lab for their support and assistance. Especially Dan Bert, whom I'm convinced, could solve any problem thrown at him, whether it be technical, logistical or otherwise. You guys are an amazing group and I'm so lucky to have been able to work with you for the past two years.

Special thanks go out to those who helped me in the field, most notably, Shaun Turney, for his undying enthusiasm and dedication. Your eagerness to learn about anything and everything is inspiring. I really enjoyed working with you and wish you all the best with your future endeavours. I would also like to thank Sarah Larocque for showing me the ropes in the beginning stages of this project, when catching and handling turtles was a brand new concept to me.

Finally, I would like to extend my sincerest appreciation to my friends, and especially my family. I am forever grateful for your unconditional love and support. 


\section{Table of Contents}

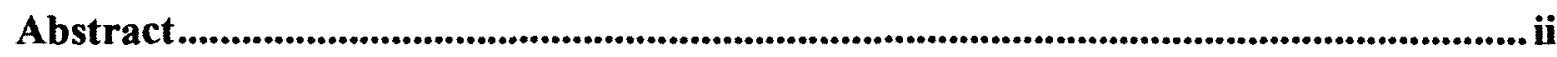

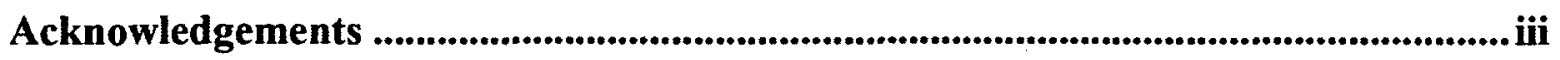

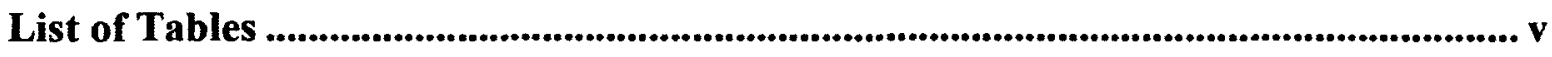

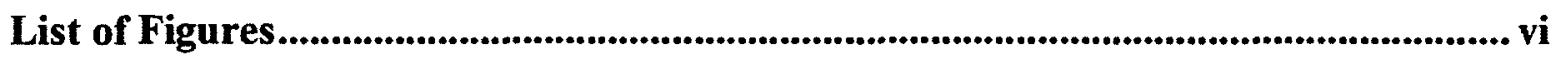

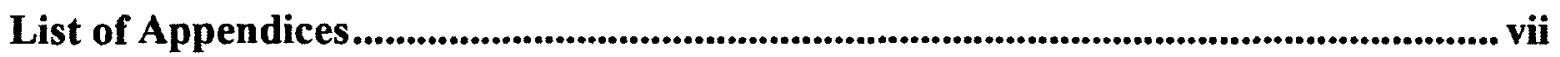

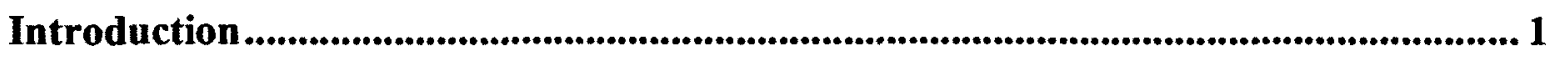

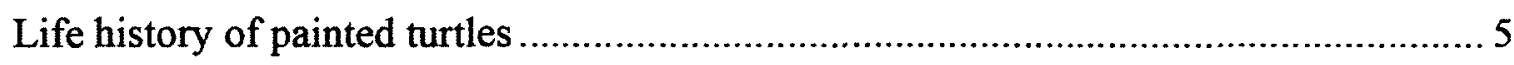

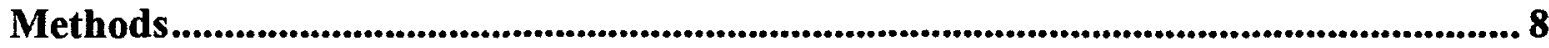

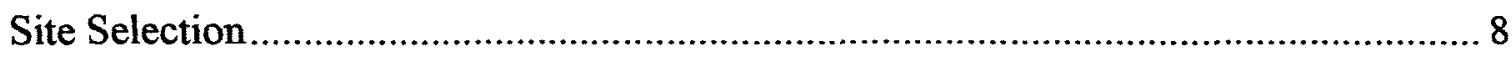

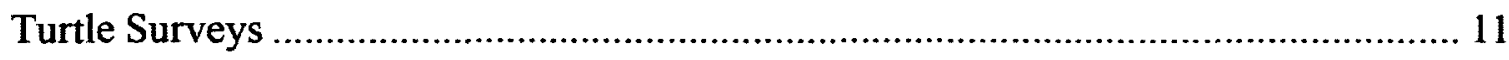

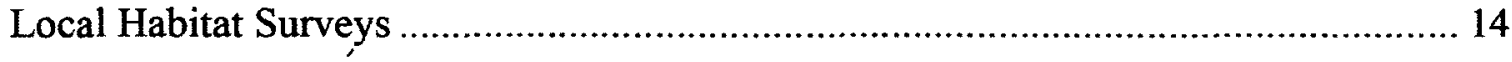

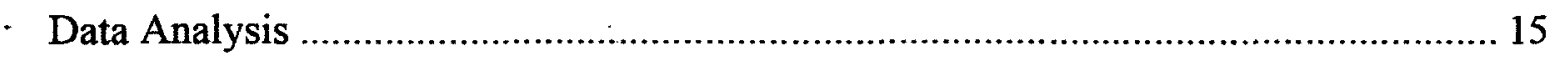

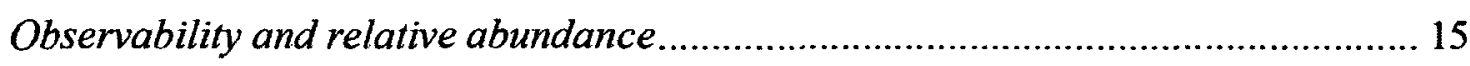

Frequency of males and females at Road vs. No Road sites ............................... 17

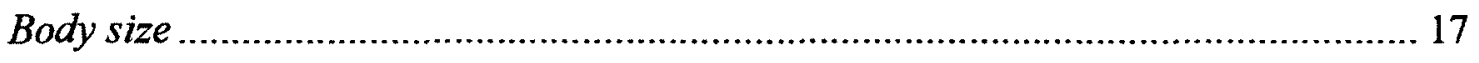

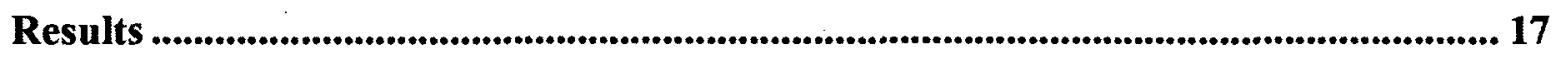

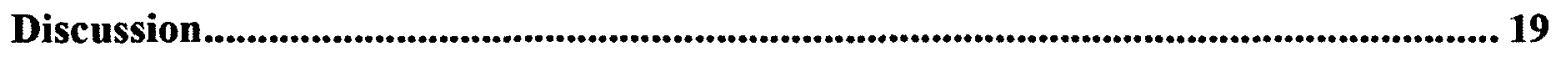

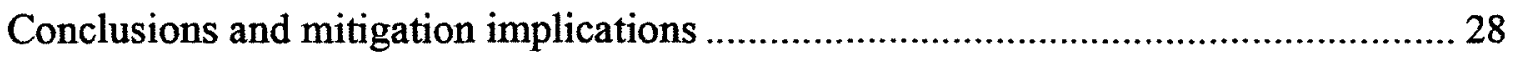

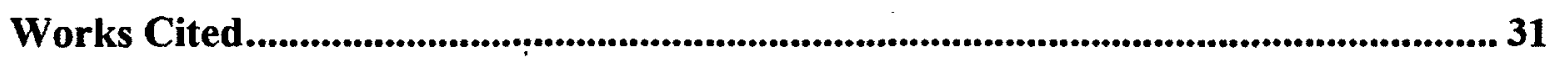

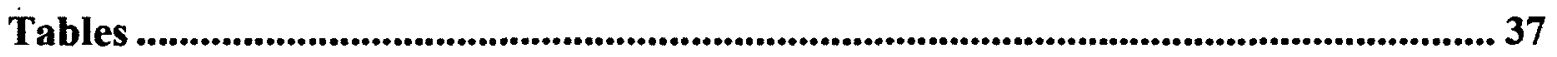

Figures............................................................................................................................... 41

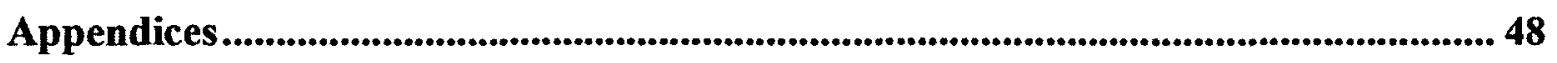




\section{List of Tables}

Table 1. Summary of pond size and surrounding area at each Road (R) and No Road (NR) site. Road age applies to the high traffic road at each Road site and total traffic volume (total AADT) is the Average Annual Daily Traffic (AADT) on each road multiplied by the total length of the road within a $300 \mathrm{~m}$ radius of each pond. Percent forest cover, crop cover and urban area are measured within a $300 \mathrm{~m}$ radius of the pond.

Table 2. Results of t-tests comparing local and landscape variables at Road and No Road sites. Variables (a) - (d) were estimated within a $5 \mathrm{~m}$ radius of the pond edge, variables $(e)-(j)$ were estimated at the surface of each pond and variables $(k)-(m)$ were estimated within a $300 \mathrm{~m}$ radius of each pond.

Table 3. Results of simple linear regressions using square root-transformed Turtle Observations as the response variable. Predictor variables (a) - (d) were estimated within a $5 \mathrm{~m}$ radius of the pond edge, variables (e) - (j) were estimated at the surface of each pond and variables $(\mathrm{k})-(\mathrm{m})$ were estimated within a $300 \mathrm{~m}$ radius of each pond.

Table 4. Results of three multiple linear regressions using square root transformed Turtle Observations as the response variable and (a) Observability index and site type (Road vs. No Road, where Road =1 and No Road =0), (b) Observability index and road density and (c) Observability index and total traffic volume (total AADT) as predictor variables 


\section{List of Figures}

Figure 1. Distribution of the 20 ponds $(10 \operatorname{Road}(\bullet ; R)$ and 10 No Road (o; NR) sites) sampled across eastern Ontario from June ${ }^{\text {st }}$ to August $28^{\text {th }}, 2011$. Ponds were paired based on geographic proximity, with the exception of one pair that was separated by a relatively large distance compared to the other pairs (pair G). Paired sites share the same capitol letter $(\mathrm{A}-\mathrm{H})$, based on the order in which they were sampled, beginning with pair $\mathrm{A}$. The study region was divided into four areas: north-east [NE], south-east [SE], south-west [SW] and north-west [NW], shown by the dashed lines, with one pair of ponds from each area being sampled in a rotational manner

Figure 2. Summary of the sampling protocol. Ponds were paired (pond $1=$ white box, pond 2 grey box) and sampled twice daily for 3 consecutive days twice during the summer (totalling 6 sampling days at each pond). Sampling days were divided into 4 periods: Morning 1 (M1), Morning 2 (M2), Afternoon 1 (A1) and Afternoon 2 (A2) such that each of the ponds within a sampling pair was visited once in the morning and once in the afternoon each sampling day. The order of visits alternated each day

Figure 3. Example of one of the hoopnets used during the study. (a) shows, on land, how a hoopnet is set up once it is in the water; (b) shows a hoopnet set up at a pond with an added floatation device to allow trapped turtles constant access to the surface for air. Two hoopnets $(61 \mathrm{~cm}$ diameter, $183 \times 91 \mathrm{~cm}$ wings, $3.8 \mathrm{~cm}$ square nylon netting) were installed at each site with the open end facing shore. Nets were baited with sardines and left in place for the duration of each three consecutive day period.

Figure 4. One of the permanent unique marks given to each turtle that was captured. Marks were made by drilling a small hole in the outer edge of two marginal scutes.

Figure 5. The number of Turtle Observations (square root transformed) at Road (•) and No Road $(\mathrm{O})$ sites plotted against Observability index.

Figure 6. The number of male and female turtles captured at Road and No Road sites.

Figure 7. Mean body size of captured males ( $\square$ ) and females ( $\square$ ), measured as straight line carapace length in $\mathrm{mm}$, across Road and No Road sites. 


\section{List of Appendices}

Appendix A. The number of turtle observations made between June $1^{\text {st }}$ and August $28^{\text {th }}$, 2011. "Turtle Observations" include all observations that were affected by observability (turtle sightings and turtles captured by dipnet or by hand). "Maximum Basking Observations" is the highest number of turtle Basking Observations made during a single visit. "In-water Observations" include all observations made while turtles were swimming in the water.

Appendix B Turtles captured by dipnet or hoopnet between June $1^{\text {st }}$ and August $28^{\text {th }}, 2011$. Sex was determined using secondary sex characteristics: the male cloacal opening extends past the posterior edge of the carapace while the female's does not. Males also have much longer foreclaws. I used the carapace length of the smallest identifiable male I sampled as the minimum size for assigning sex

Appendix C. Summary of the local variables estimated at each site. Percent area covered by forest, grass, shrub and open ground (such as dirt or gravel) were estimated within a $5 \mathrm{~m}$ radius of the pond edge. Percent cover by openwater, emergent vegetation and submerged vegetation were all estimated at the pond surface. $\mathrm{pH}$, temperature and conductivity were measured at the pond surface

Appendix D. Results of four multiple linear regressions using square roottransformed Maximum Basking Observations as the response variable and (b) pond size with site type (Road vs. No Road, where $\operatorname{Road}=1$ and No Road $=0$ ), (c) pond size with road density $\left(\mathrm{m} / \mathrm{km}^{2}\right.$ ) and (d) pond size with total traffic volume (total AADT) as predictor variables

Appendix E. Results of four simple linear regressions using square roottransformed Maximum Observations as the response variable and (a) pond size (perimeter in $\mathrm{m}$ ), (b) site type (Road vs. No Road, where Road = 1 and No Road = 0 ), (c) road density $\left(\mathrm{m} / \mathrm{km}^{2}\right.$ ) and (d) total traffic volume (total AADT) as predictor variables 


\section{Introduction}

Turtle populations have been declining over the past several decades (Wilbur 1975, Garber and Burger 1995, Gibbons et al. 2000, Ernst and Lovich 2009). Canada is home to eight species of freshwater turtles, each of which is listed as either endangered, threatened or a species of special concern under the Canadian Species at Risk Act (SARA) in one or more of its regions of occurrence (Government of Canada 2011). Turtle life history is characterized by high hatchling mortality, delayed sexual maturity and high adult survivorship; thus any threat that decreases adult numbers has the potential to greatly impact the persistence of the population (Gibbs and Shriver 2002, Bulté et al. 2010).

There are several possible causes for turtle population decline including mortality caused by turtle bycatch in inland fisheries (Dorcas et al. 2007, Bury 2011, Larocque et al. 2012), mortality and disturbance caused by recreational boating (Galois and Ouellet 2007, Bulté et al. 2010), and turtle collection for consumption purposes or for the pet trade (Wood and Herlands 1997, Schlaepfer et al. 2005). Another possible cause is habitat destruction or alteration, including the construction or expansion of residential and commercial developments (Garber and Burger 1995, Wood and Herlands 1997, Findlay and Bourdages 2000, Ernst and Lovich 2009). An increase in human development also increases the risk of predation on turtles and their nests as the abundances of common predator species associated with humans, such as raccoons (Procyon lotor), foxes (Vulpes vulpes), coyotes (Canis latrans) and domestic dogs (Canis lupus familiaris) and cats (Felis catus) increase as well (Christens and Bider 1987, Temple 1987). 
With any new or expanding human development comes the need for roads. Road mortality is thought to be one of the primary causes of turtle population decline, as many turtles are found dead on roads each year (Ashley and Robinson 1996, Wood and Herlands 1997, Marchand and Litvaitis 2004a, Aresco 2005a, Gibbs and Steen 2005, Beaudry et al. 2008). Road mortality is reported as a principal threat to turtle populations in seven of the ten population status reports for the turtle species listed on the SARA Public Registry (Government of Canada 2011).

Despite the fact that roads are thought to have a negative effect on turtle abundance, there is no direct evidence to date that roads actually cause declines in turtle populations. Rather, the inference that roads reduce turtle populations is based on indirect evidence, most notably altered sex ratios in turtle populations near roads. Male-biased sex ratios in turtle populations near roads (Baldwin et al. 2004, Marchand and Litvaitis 2004a, Steen and Gibbs 2004, Aresco 2005a, Gibbs and Steen 2005) have been interpreted as evidence that roads affect turtle population viability. Male-biased sex ratios are thought to be due to higher road mortality rates of female turtles than males because females often travel over land in search of suitable nesting sites, thus potentially coming into contact with roads (Baldwin et al. 2004, Aresco 2005a). In addition, females commonly use the loose substrate along road edges for nesting sites, further increasing their chance of being killed by a vehicle (Mahmoud 1968, Wood and Herlands 1997, Aresco 2004). This scenario has been supported by several studies which have found proportionally more female turtles dead on roads than males (reviewed in Steen et al. 2006). It has been argued therefore that male-biased sex ratios are a sign of turtle 
populations in imminent danger of population decline (Marchand and Litvaitis 2004a, Steen and Gibbs 2004).

While many studies have suggested that roads should have a strong negative effect on turtle populations (e.g.: Ashley and Robinson 1996, Wood and Herlands 1997, Marchand and Litvaitis 2004a, Aresco 2005a, Gibbs and Steen 2005, Beaudry et al. 2008), there is some debate. Gibbs and Shriver (2002) conducted a modelling study to investigate the effects of roads on turtle population persistence by simulating turtle movements in urban and rural landscapes of varying road density and traffic volumes. They modelled annual road-associated mortality in the United States for three groups of turtles (1-land turtles such as box turtles (Terrapene), 2-small bodied pond turtles such as painted turtles (Chrysemys picta) and 3-large bodied pond turtles such as snapping turtles (Chelydra serpentina)) by estimating the probability of a turtle being killed while crossing a road and the number of annual road crossings in landscapes of differing road density and traffic volume. They used this model in conjunction with traffic volume and road density data for each U.S. state to determine how different levels of annual road mortality should affect population persistence. While they found that roads had the potential to decrease population size in land and large-bodied pond turtles, no such effect was found for small-bodied pond turtles. Note however that Gibbs and Shriver's (2002) average estimate of annual road mortality for small-bodied pond turtles was much less than the estimate of approximately $5 \%$ provided by Bradford (2003) for a painted turtle population in the St Lawrence Islands National Park, a park found in the same geographic area as the sampled ponds in the current study. 
At least two studies have attempted to test the effects of road density on painted turtle population structure and abundance - Marchand \& Litvatis (2004a), and Steen \& Gibbs, (2004) - but no significant effects on population size were found. Thus, to the best of my knowledge, there are no studies empirically demonstrating that turtle population abundance or distribution is negatively affected by roads. The authors offer two main explanations for this lack of effect. First, they suggest that perhaps no effects have yet been observed because the turtle populations being studied are in areas where roads are relatively new, thus not enough time has passed for an observable negative effect of road mortality on the population to be apparent (Findlay and Bourdages 2000, Steen and Gibbs 2004). Secondly, accurate abundance estimates for turtles are notoriously difficult to make due to the high variability in turtle observability and catchability. Trying to avoid these issues often leads to small sample sizes in terms of the number of populations compared (e.g., near roads vs. far from roads); when more sampling effort is needed to estimate each population, fewer populations can be studied.

My primary objective was to design a study that overcomes, to the extent possible, these difficulties and provides a test of the prediction that road mortality reduces turtle populations. I compared relative abundance of painted turtles (Chrysemys picta marginata) in 20 ponds across eastern Ontario, 10 as close as possible to high traffic roads and 10 as far as possible from any major roads. Painted turtles are abundant enough in eastern Ontario to allow estimates of relative abundance to be made over a single sampling season, and while the Ontario populations are not currently listed under SARA (Government of Canada 2011), painted turtles are certainly not immune to road mortality (e.g.: Ashley and Robinson 1996; Baldwin et al. 2004; Marchand and Litvaitis 2004a). I 
selected only ponds and roads that had been in place for several decades so that the effects of past road mortality on the population would be observable. I also measured variables that influence painted turtle observability and controlled for variance due to observability in estimating turtle relative abundance.

Although results of the modelling study done by Gibbs and Shriver (2002) suggest that populations of small-bodied pond turtles, such as painted turtles, may not be negatively affected by roads, road mortality is listed as a primary threat to the endangered Western painted turtle population in Canada's Rocky mountains (Government of Canada 2011) and several studies have found male-biased sex-ratios in small-bodied turtle populations near roads (Baldwin et al. 2004, Marchand and Litvaitis 2004a, Steen and Gibbs 2004, Aresco 2005a, Gibbs and Steen 2005), presumably demonstrating that roads do have the potential to negatively impact even small-bodied pond turtles like the painted turtle. My goal was to design a study with a high likelihood of detecting an effect of high traffic roads on painted turtle populations, if such an effect is present. I predicted that turtle populations would be absent altogether, or in the very least, extremely male-biased in ponds close to high traffic roads. If, as predicted, high traffic roads do have a strong negative impact on painted turtle populations, this should be evident in the current study.

\section{Life history of Painted turtles}

Within Canada, painted turtles are found from the south-west coast of British Columbia across the entire southern region of Canada and into Nova Scotia. Their U.S. range is spotty in the west but extends over the northern border with Canada and down through the eastern half of the country to the Gulf of Mexico. Painted turtles are the only 
species of turtle found across the entire North American continent (Ernst and Lovich 2009). There are four subspecies of painted turtle. The southern painted turtle's (Chrysemys picta dorsalis) range does not extend north of southern Illinois. The western painted turtle (Chrysemys picta belii) is found within Canada, ranging from western Ontario to British Columbia, with the Rocky Mountain population listed as a special concern species under SARA (Government of Canada 2011). The eastern painted turtle's (Chrysemys picta picta) Canadian range stretches from eastern Québec into Nova Scotia. The midland painted turtle (Chrysemys picta marginata) ranges, within Canada, from south-western Ontario into eastern Québec. The midland painted turtle is the only painted turtle subspecies found within my study region (Ernst and Lovich 2009) and is not currently listed as a species at risk SARA (Government of Canada 2011).

With such a broad range comes a diversity of habitat types and preferences. In general, however, painted turtles prefer shallow slow-moving water such as that found in ponds, swamps, creeks, and some rivers and lakes. Along the south-western reaches of their range, they are found primarily in open bodies of water such as lakes and wide rivers (Bury and Germano 2003) while farther north they are found most frequently in wetlands and ponds surrounded by forest (Findlay and Houlahan 1997, Baldwin et al. 2004). Turtles are mainly diurnal (Ernst, 1971a), and spend much of their time in summer basking in the sun (Ernst 1971, Lefevre and Brooks 1995). Painted turtles prefer water bodies with soft bottom substrate because in the northern reaches of their range at least, they over-winter by burying into the substrate (Ernst and Lovich 2009).

Painted turtles are precocial and grow rapidly during their first few years (Ernst and Lovich 2009). Although growth slows considerably during later years it does not stop 
entirely, meaning that they exhibit indeterminate growth (Gibbons 1968, Congdon et al. 2003, Ernst and Lovich 2009). Painted turtles are sexually dimorphic with females being larger than males (Wilbur 1975, Mitchell 1988, Ernst and Lovich 2009). Attainment of sexual maturity depends on body size rather than age and is highly variable, not only between populations in differing latitudes (Moll 1973, Shine and Iverson 1995), but also from year to year within a single region (Frazer et al. 1993). However, sexual maturity is generally reached at 4-6 years in males and 7-10 years in females (Gibbons 1968, Wilbur 1975, Mitchell 1988, Frazer et al. 1993). Turtles in the northern parts of their range generally take longer to reach sexual maturity (Mitchell 1988).

The majority of females nest annually (Tinkle et al. 1981, Mitchell 1988, Ernst and Lovich 2009), with some nesting multiple times in a single season (Moll 1973, Snow 1980, Tinkle et al. 1981, Krawchuk and Brooks 1998). While males are known to move over land occasionally in search of mates, it is primarily the females that travel terrestrially in search of potential nesting sites (Christens and Bider 1987, Aresco 2005a). The majority of terrestrial movements made by painted turtles are short, straight-line movements averaging 54 to $200 \mathrm{~m}$ from the pond edge (Christens and Bider 1987, Burke and Gibbons 1995, Rowe 2003, Baldwin et al. 2004, Caldwell and Nams 2006), with some longer distance movements occurring as well (>1 km; Bowne and White 2004, Caldwell and Nams 2006).

In June and early July females bury clutches of 3-10 eggs (Wilbur 1975, Tinkle et al. 1981, Mitchell 1988) in loose substrate, such as sand, dirt, gravel or grass (Christens and Bider 1987, Baldwin et al. 2004, Ernst and Lovich 2009). Sex determination of the young occurs during the incubation period and is temperature dependent, with 
temperatures less than $20^{\circ} \mathrm{C}$ and greater than $28^{\circ} \mathrm{C}$ producing almost exclusively females and temperatures in-between producing almost exclusively males (Gutzke and Paukstis 1984, Ewert and Nelson 1991). After hatching, the young remain in the nest until the following spring (Wilbur 1975, Tinkle et al. 1981, Mitchell 1988). Nest failure and within-nest hatchling mortality rates are high, ranging from $30 \%$ to over $90 \%$ with the majority being due to nest predation (Wilbur 1975, Tinkle et al. 1981, Christens and Bider 1987, Mitchell 1988, Aresco 2004). Once past the hatchling stage (0-1 years), however, survivorship increases dramatically with adults generally showing survivorship rates of over $90 \%$ annually (Mitchell 1988). Most painted turtles live for approximately 30-40 years (Ernst and Lovich 2009); however, individuals over the age of 60 years have been observed (Congdon et al. 2003).

\section{Methods}

\section{Site Selection}

I selected 20 permanent ponds across eastern Ontario, 10 of which were close to a freeway, highway or a major arterial road ("Road" sites; mean distance from high traffic $\operatorname{road} \pm \mathrm{SE}=65 \pm 10 \mathrm{~m}$ ), while the other 10 were as far as possible from any major roads ("No Road" sites; mean distance from closest major road $=1517 \pm 285 \mathrm{~m}$ ) (Figure 1;

Table 1). I used a distance of $300 \mathrm{~m}$ from each pond as the minimum distance to a major road for selection of No Road sites (Table 1), as land-based movements of most painted turtles occur within $300 \mathrm{~m}$ of the pond (Christens and Bider 1987, Burke and Gibbons 1995, Rowe 2003, Baldwin et al. 2004, Caldwell and Nams 2006). Although I attempted to only select ponds for my No Road sites that had no roads at all within a $300 \mathrm{~m}$ radius 
of a point at the centre of each pond, this was not possible to do in all cases while also keeping other potentially confounding local and landscape variables similar between Road and No Road sites. Three of the 10 No Road sites had no roads at all within a 300 $m$ radius of the pond, three had one unpaved road (one of which lead to a dead end), and the remaining four No Road sites had one minor paved road within $300 \mathrm{~m}$ radius of the pond. Major roads included any road that was classified as an arterial road, highway, expressway or freeway, while minor roads included any road that was classified as a local/street or collector road (Ontario Ministry of Natural Resources 2010a).

If road mortality due to collisions with vehicles reduces turtle populations, and the probability of a crossing turtle being struck and killed by a vehicle increases with traffic volume (Aresco 2005b), then this negative effect should be most apparent at ponds near roads with very high traffic volumes. Traffic volume is measured as the Average Annual Daily Traffic (AADT) and represents the average traffic occurring every 24 hours between January $1^{\text {st }}$ and December $31^{\text {st }}$ (Ontario Ministry of Transportation 2008). I selected ponds for the Road sites that were along major highways and roads with very high traffic volumes ( 6900 to 73932 AADT; mean $=20784$ AADT). Traffic on the roads within $300 \mathrm{~m}$ of ponds in the No Road sites ranged from 50 to 500 AADT (mean $=350$ AADT). To compare traffic across Road and No Road sites, I calculated the total AADT within a $300 \mathrm{~m}$ radius of each pond by multiplying the AADT on each road by the length of the road (in $\mathrm{km}$ ) within the $300 \mathrm{~m}$ radius. Total AADT within $300 \mathrm{~m}$ radius of ponds ranged from 3421.3 to 79146.9 (mean $=18492.2$; Table 1$)$ at Road sites and from 0 to $311.8($ mean $=112.3 ;$ Table 1$)$ at No Road sites. Although some turtles are killed on gravel and minor roads like the ones within $300 \mathrm{~m}$ radius of the No Road sites (e.g. 
Marchand and Litvaitis 2004a), traffic volume averaged almost sixty times greater along the high traffic roads at the Road sites than it did along the minor roads at the No Road sites, presumably resulting in much greater road associated mortality at the Road sites. Traffic volume was determined for seven of the ten Road sites using 2008 data provided by the Ontario Ministry of Transportation (Ontario Ministry of Transportation 2008) and for the three remaining Road sites, using 2011 data provided by the City of Ottawa (unpublished data). Traffic data was not available for the minor roads within a $300 \mathrm{~m}$ radius of ponds, thus AADT estimates were made using the procedure outlined in Eigenbrod et al. (2008). They conducted two 15 minute traffic counts on their roads of interest (with unknown traffic volume) and on similar roads in the area (with known traffic volume). For the roads with known traffic volumes they determined the ratio of the traffic volume measured during the 15 minute count to the known traffic volume, then using this ratio, they were able to make traffic volume estimates for their roads with previously unknown traffic volumes. In addition to traffic volume, I measured road density $\left(\mathrm{m} / \mathrm{km}^{2}\right)$ within a $300 \mathrm{~m}$ radius of each pond using the Ontario Road Network dataset (Ontario Ministry of Natural Resources 2010a).

I tried to find ponds and highways that were well established, meaning neither pond nor highway had recently been created or built, using the rationale that selecting ponds and roads that have been in place for several decades would increase the probability of seeing an effect on the painted turtle population (Findlay and Bourdages 2000). The 20 ponds ranged in age from 25 to 90 years (mean $=50$ years; Table 1 ) and the high traffic roadways associated with the Road sites ranged in age from 38 to 90 years $($ mean $=55$ years; Table 1 ). Ages of ponds and roads were assessed using air photos from 
the Canadian National Air Photo Library and through personal communication with land owners.

Ponds ranged in size from $553 \mathrm{~m}^{2}$ to $19877 \mathrm{~m}^{2}$ (mean $=6380 \mathrm{~m}^{2}$; Table 1$)$, and were a minimum of $4.5 \mathrm{~km}$ apart (Figure 1). The amount of forest in the surrounding landscape has been shown to affect turtle abundance in nearby wetlands (Findlay and Houlahan 1997, Marchand and Litvaitis 2004a) so I attempted to select sites such that the Road and No Road sites had similar amounts of forest within $300 \mathrm{~m}$ of the ponds (Table 1). I also attempted to keep the amount of crop cover within a $300 \mathrm{~m}$ radius similar between Road and No Road sites as well as keeping urban area (any area where structures exceed 4 per $10000 \mathrm{~m}^{2}$; Ontario Ministry of Natural Resources 2007) low and similar between the Road and No Road sites (Table 1). In addition, I selected only ponds that did not have another obvious water source (including wetlands, lakes, rivers or other ponds) within $250 \mathrm{~m}$ (mean distance to nearest body of water $\pm \mathrm{SE}=372 \pm 27 \mathrm{~m}$; Table 1). The amount of forest and urban area within a $300 \mathrm{~m}$ radius of each pond was determined using Ontario Ministry of Natural Resources thematic data (Forest cover: Ontario Ministry of Natural Resources 2010b; Urban Area: Ontario Ministry of Natural Resources 2007) while the amount of crop cover was determined using aerial photos from 2008 and 2009 (Ontario Ministry of Natural Resources 2009). I used ArcMap 10.0 (ESRI, Redlands, California, USA) for all geographic information systems (GIS) analyses.

\section{Turtle Surveys}

Turtle surveys took place between June $1^{\text {st }}$ and August $28^{\text {th }}, 2011$. For sampling purposes, ponds were paired based on geographic proximity with the exception of one 
pair that was separated by a relatively large distance compared to the other pairs (pair G; Figure 1). The eastern Ontario study region was divided into four areas: north-east, southeast, south-west and north-west (Figure 1). I sampled one pair of ponds in each of the four geographic areas in a rotational manner such that all areas of the study region were sampled evenly throughout the sampling period. Four of the ten pairs contained one Road and one No Road site while three pairs contained two Road sites and three pairs contained two No Road sites. Despite this, Road and No Road sites were sampled evenly throughout the sampling period.

Each pair of ponds was sampled twice a day for three consecutive days twice throughout the summer for a total of six sampling days at each pond. Each sampling day was divided into four sampling periods: Morning 1 (M1, 08:00 - 10:20), Morning 2 (M2, 09:30 - 12:30), Afternoon 1 (A1, 12:30 - 14:30) and Afternoon 2 (A2, 13:15 - 16:45) such that each pond within a sampling pair was visited once in the morning and once in the afternoon each sampling day (Figure 2). The order of visits alternated each day so that the pond that was visited during Ml and Al sampling periods on the first day would be visited during the $\mathrm{M} 2$ and $\mathrm{A} 2$ sampling periods on the following day, and vice versa (Figure 2). After all 20 sites had been visited twice a day for three consecutive days (between June $6^{\text {th }}$ and July $22^{\text {nd }}, 2011$ ), the entire process was repeated, and each site was visited twice a day for another three consecutive days (between July $25^{\text {th }}$ and August $28^{\text {th }}$, 2011). To ensure the same time interval for all sites between the first and second sampling periods, pairs of ponds were visited in the same order during the second sampling period as they were during the first, with the exception of two pairs that reversed order during the second sampling period. 
Each sampling period began with a single, slow, meticulous unidirectional search for painted turtles along the perimeter ( $<3 \mathrm{~m}$ from shore) of the pond either by canoe or by foot. I recorded turtles seen and I attempted to catch, with a dipnet or by hand, every turtle that was seen. On the first day of the three-day period, directly following the perimeter search during the morning sampling period, two hoopnets $(61 \mathrm{~cm}$ diameter, 183 x $91 \mathrm{~cm}$ wings, $3.8 \mathrm{~cm}$ square nylon netting; Figure 3) were installed at the pond. Each hoopnet was placed with the open end facing the shoreline and baited with a partially opened can of sardines (Mitchell 1988, Roe et al. 2011). A floatation device was placed near the closed end of each net to allow trapped turtles access to the surface. The hoopnets were placed in areas where I had seen turtles during the perimeter search or, if no turtles had been seen, they were placed near areas that provided suitable basking habitat (including fallen logs or emergent rocks along the shoreline). Hoopnets were left in place for the duration of the three-day period, and were checked for turtles following the perimeter searches during each subsequent visit after initial set-up. The hoopnets were removed from the pond following the morning perimeter search on the last day of a three consecutive day period (Figure 2).

All turtles caught were weighed using a Starfrit $5 \mathrm{~kg}$ digital scale $( \pm 1 \mathrm{~g})$ and their straight-line carapace length, width and depth were measured using a transfer caliper. Sex was determined using secondary sex characteristics: the male cloacal opening is located on the portion of tail that extends past the posterior edge of the carapace while the female cloacal opening is located on the portion of the tail that does not extend past the posterior edge of the carapace. Additionally, males have much longer foreclaws than females (Ernst and Lovich 2009). Sex can only be determined after reaching sexual maturity, and 
size at sexual maturity in painted turtles is highly variable (Moll 1973, Frazer et al. 1993, Shine and Iverson 1995). While sexually mature males are easily identified, sexually mature females are larger versions of juveniles and can therefore only be determined by size or gravidity. For this reason I used the carapace length of the smallest identifiable male I sampled as the minimum size for assigning gender. That is to say, any non-male turtle that was larger than the minimum carapace length was classified as a female and any turtle smaller than the minimum carapace length was classified as a juvenile of unknown gender. Each captured turtle was given a unique carapace mark by drilling a small hole in the outer edge of two marginal scutes (Bulté and Blouin-Demers 2009; Figure 4). Turtles were released immediately after being weighed, measured and marked. Any recaptures were recorded and then released immediately.

Methods were approved by the Carleton University Animal Care Committee and the appropriate permits were obtained from the Ontario Ministry of Natural Resources.

\section{Local Habitat Surveys}

Vegetation surveys took place between July $25^{\text {th }}$ and August $28^{\text {th }}, 2011$. Each site was surveyed once. Marchand and Litvaitis (2004a) found that shoreline vegetation composition and percent surface cover by herbaceous-emergent vegetation were significantly related to turtle abundance. Therefore, I conducted a visual survey of the surface of each pond, recording the percent surface covered by open water, emergent vegetation and submerged aquatic vegetation that reached, but did not break the surface. I also conducted a visual survey of adjacent upland local habitat, including percent area covered by forest, shrubs, grass and open ground (dirt, sand or gravel) within $5 \mathrm{~m}$ of the shoreline. I measured temperature, $\mathrm{pH}$ and conductivity at random surface locations of 
each pond immediately following each turtle survey using a Hanna Instrument handheld tester (HI 98129).

\section{Data Analysis}

Although I tried as much as possible to control for potentially confounding variables during site selection, there were still some variables potentially affecting turtle abundance that I was unable to pre-emptively control for, such as the local habitat variables mentioned above. Thus preliminary analyses were conducted using a series of two-tailed t-tests assuming either equal or unequal variances (depending on the results of a Levine's test for equality of variances) to determine whether any of the potentially confounding variables differed significantly between the Road and No Road sites.

During each visit, all turtle observations were assigned to one of three mutually exclusive categories: (1) Sightings, (2) Captured by dipnet or by hand, or (3) Captured by hoopnet. Data subsets were created as follows: "Turtle Observations" represented sightings and captures that were affected by observability (see below) and included all turtle sightings and turtles captured either by dipnet or by hand (ie: (1) + (2)). "Turtles Captured" included turtles that were captured either by dipnet, by hand or by hoopnet and individually marked (ie: (2) $+(3)$ ).

All statistical analyses were conducted using SPSS version 19.0. All data and residuals were screened for normality and transformed as necessary. The response variable Turtle Observations was square root transformed for all analyses.

\section{Observability and relative abundance}

Reliable estimates, even relative estimates, of turtle populations are difficult to obtain because of the many factors that can influence an observer's ability to detect 
turtles. These include water clarity, water depth and whether or not there is submerged vegetation obstructing the view to the bottom. These factors must be taken into account when comparing relative turtle abundance between Road and No Road sites. In addition, while I attempted to standardize the sizes of the ponds, there was inevitably variation in pond size (Table 1). The effect of pond size must be controlled for when testing for a difference in turtle relative abundance between the Road and No Road sites. I therefore created a single "Observability" index as the product of pond size and visibility. Pond size was measured as the perimeter of the pond in meters and visibility was measured as the average visible depth in centimeters. If the water was perfectly clear and there was no vegetation obstructing the view, visibility was taken as the depth of the pond, to a maximum of $150 \mathrm{~cm}$, as this was the maximum depth at which observations were made. Otherwise, visibility was based on secchi disk readings. The observability index provides a standardized estimate of the searchable volume of water at each pond.

To validate the Observability index I conducted a simple linear regression of Turtle Observations on Observability. In addition, I individually regressed Turtle Observations on each of the potentially confounding local and landscape variables to determine whether any of them were significantly related to turtle relative abundance. Finally, I conducted 3 multiple linear regressions, each using Turtle Observations as the response variable, Observability index as one predictor variable and with site type (Road vs. No Road; where Road $=1$ and No Road $=0$ ), road density or total traffic volume (AADT) within a $300 \mathrm{~m}$ radius of the pond as a second predictor variable. 
Frequency of males and females at Road vs. No Road sites

In addition to my main objective of comparing turtle relative abundance at Road and No Road sites, I compared the frequency of males and females captured at Road and No Road sites. If females are killed more frequently on roads than males, I expected to see a male-biased sex-ratio and a larger difference in frequency of captures of females than males between Road and No Road sites. To test this prediction I performed a chisquare test of independence on the number of males and females captured (Turtles Captured with juveniles removed) at Road and No Road sites.

\section{$\underline{B o d y \text { size }}$}

Furthermore, I evaluated whether average body size of captured turtles was less at Road than at.No Road sites. I reasoned that if adult turtles are being killed by vehicles when they undertake over-land movements, then over time, this increased mortality of adults should lead to an overall decrease in body size in the population. To test this I conducted two one-tailed t-tests using square root transformed Turtles Captured (with juveniles removed) as the response variable. One compared average body size (measured as straight-line carapace length in $\mathrm{mm}$ ) of females at Road and No Road sites while the other compared average body size of males at Road and No Road sites.

\section{Results}

None of the potential confounding local or landscape variables differed significantly between the Road and No Road sites (Table 2), indicating that I had successfully selected similar ponds in the two categories. 
Turtle Observations totalled 497 (221 at Road sites and 276 at No Road sites; Appendix A). While these numbers likely include several re-sightings of the same individuals on subsequent visits, they should still provide a good estimate of relative population abundance across all sites. Of the turtles that were caught, 40 were female, 32 were male and 4 were juvenile (Appendix B). There were two ponds (both at No Road sites) where I did not observe any turtles over the entire three month sampling period (Appendix A).

Observability scores did not differ significantly between Road and No Road sites $(t=-0.199, d f=18, p=0.845)$. There was a significant positive relationship between Observability score and Turtle Observations $(\beta=0.641 ; F=12.5405, d f=1,18, p=$ 0.002 ; Figure 5), with the Observability index accounting for just over $40 \%$ of the variation in Turtle Observations $\left(R^{2}=0.411\right.$; Figure 5). Therefore I included Observability in further analyses of Turtle Observations to account for variability due to observability and pond size.

I conducted simple linear regressions of Turtle Observations on each of the potentially confounding predictor variables. None was significantly related to Turtle Observations (Table 3), and thus they were not included in further analyses. The multiple regressions of Turtle Observations on Observability and each of site type (Road vs. No Road), road density and total traffic volume, revealed no significant effect of the road and traffic variables on relative turtle abundance (Table 4).

Contrary to predicted, more of the captured and sexed turtles at Road sites were females, however this trend was not statistically significant (Pearson's $X_{(n=72)}^{2}=0.494$, $d f=1, p=0.482$; Figure 6 ). While males showed no significant difference in average 
body size between Road and No Road sites $(t=0.026, d f=30, p=0.979$; Figure 7), females were significantly larger at Road sites than at No Road sites $(t=-2.737, d f=38$, $p=0.009 ;$ Figure 7 )

\section{Discussion}

The purpose of this study was to conduct a test of the prediction that road mortality reduces painted turtle populations. Road mortality is commonly high among turtles, especially in females, and has therefore been thought to negatively impact turtle populations (Mahmoud 1968, Ashley and Robinson 1996, Wood and Herlands 1997, Aresco 2004, Baldwin et al. 2004, Marchand and Litvaitis 2004a, Aresco 2005a, Gibbs and Steen 2005, Beaudry et al. 2008). Yet empirical evidence of the direct negative effects of road mortality on turtle populations is lacking. I compared painted turtle relative abundance at 10 ponds close to high traffic roads and 10 ponds far from high traffic roads but, contrary to what I expected, I found that painted turtle relative abundance did not differ between them, suggesting that road mortality, which I assumed to be very high along high traffic roads, does not have a negative impact on these painted turtle populations.

There are two possible reasons that could explain why I did not find a relationship between the presence of high traffic roads and painted turtle relative abundance: (1) The predicted negative effect of road mortality on painted turtle populations was present but I was simply not able to detect it in the current study, or (2) although many painted turtles are killed on roads each year, there is in fact no overall negative effect on painted turtle populations. I will discuss each of these in turn. 
If road mortality does negatively affect painted turtle populations, then why was I not able to detect such an effect here? Some studies have suggested that the negative effects of road mortality may be hard to detect in areas where roads are relatively new due to life history traits of turtles, namely their longevity and delayed sexual maturity, which may cause a time lag in detecting an effect on the population (Findlay and Bourdages 2000, Steen and Gibbs 2004). It is, however, unlikely that this was an issue in this study as I selected only ponds and adjacent roads that were several decades old. Although painted turtles can live for more than 60 years (Congdon et al. 2003) and do not reach sexual maturity until they are between 7 and 10 years old for females and 4 to 6 years old for males (Gibbons 1968, Mitchell 1988, Frazer et al. 1993), the average age of the high traffic roads close to the Road site ponds was 55 years $( \pm \mathrm{SE}=4.8$ years; Table 1) and the ponds themselves averaged 50 years old ( \pm 0.9 years; Table 1$)$, presumably allowing sufficient time for road mortality to negatively affect the populations at these sites if it was going to do so.

It is possible that I was unable to detect a negative effect of roads due to confounding variables. Past studies have found that turtle abundance was correlated with certain habitat variables including, for example, the amount of forest in the landscape surrounding the wetland or pond (Findlay and Houlahan 1997, Baldwin et al. 2004) and the amount of emergent vegetation in and around the water body (Marchand and Litvaitis 2004a). However, while such variables could potentially confound the impacts of roads, I controlled for these variables and others in my study design by selecting sites that did not differ significantly in any of the measured local or landscape variables (other than road density and total traffic volume; Table 2). As none of the potentially confounding 
variables differed significantly between Road and No Road sites, and none were significantly related to turtle relative abundance (Table 3), it is highly unlikely that any of them would have confounded my ability to detect an effect of roads on painted turtle relative abundance.

Consistent and accurate abundance estimates are important when conducting a study that compares several populations. There are a couple issues that make accurate abundance estimates of true turtle population size difficult: (1) observability, and (2) sample size. I was successfully able to account for the variability due to observability differences between ponds by creating an Observability index, the product of pond size and depth of visibility. Observability did not differ significantly between Road and No Road sites; however it had a significant positive relationship with turtle relative abundance (Figure 5). By including the Observability index as a predictor variable in my multiple linear regression models looking at road effects, I accounted for the variability in relative abundance due to observability and pond size issues, thus this too was unlikely to have confounded my ability to detect an effect of high traffic roads on turtle relative abundance. Studies of a single wetland or a small group of ponds in close proximity can make relatively good population estimates after several years of intensive sampling using mark-recapture techniques (e.g.: Congdon and Gibbons 1996). However, evaluating a single or a small number of turtle populations would not represent adequate replication for testing a prediction such as the one tested here. Given the number of ponds at which I sampled and the time restriction of a single field season, actual population estimates were simply not possible. While I assumed that my measure of relative turtle abundance was correlated with actual population size at each of the ponds, I am not able to know this for 
sure. Had I been able to sample more intensively and get an estimate of true population size at a smaller sub-selection of the ponds this would have provided me with a better sense of the true relationship between my relative abundance estimates and actual population size. Despite this potential limitation, I was still able to reliably compare relative turtle abundance across sites as I used the same sampling methods at all sites. This allowed me to work under the assumption that ponds where I consistently observed more turtles likely had a larger population than ponds where I consistently observed fewer turtles. By comparing two groups of similar ponds that differed in their proximity to very high traffic roads, this study was specifically designed to target the effects of roads, which are hypothesised in the majority of the literature (e.g.: Ashley and Robinson 1996, Wood and Herlands 1997, Marchand and Litvaitis 2004a, Aresco 2005a, Gibbs and Steen 2005, Beaudry et al. 2008) to have a strong a negative effect on turtle populations. Presumably if such a strong negative effect was present, it should have been observed in the current study despite my somewhat limited sample size and the use of relative abundance instead of true population counts.

I conducted two sets of post-hoc analyses to further investigate the relationship between the Observability index and relative turtle abundance to see whether changing the measure of relative abundance would have any effect on the overall outcome of this study. First, I divided my Turtle Observations into two groups: "Basking Observations" included all observations made while turtles were basking and "In-water Observations" included all observations made while turtles were swimming in the water (Appendix A). The amount of time turtles spend basking, and thus visible for me to count during my surveys, is highly dependent on environmental conditions including cloud cover and wind 
speed, among others (Ernst and Lovich 2009). I visited each pond twice a day for a total of six days to control for variation in environmental conditions; however I attempted to further control for this variation here by using the maximum number of turtle Basking Observations made during a single visit as my response variable ("Maximum Basking Observations"; Appendix A). Presumably, the visit in which I was able to make the highest number of Basking Observations at each pond represented the day with the most optimal environmental conditions for turtle basking observations. As visible water depth had no bearing on my ability to observe basking turtles, I omitted visible water depth from the Observability index and conducted a simple linear regression of pond size (measured as the length of the perimeter in meters) on the Maximum Basking Observations. Pond size was not significantly related to Maximum Basking Observations (Appendix D), therefore I excluded it from further analyses looking at the effects of roads on Maximum Basking Observations. I subsequently conducted three simple linear regressions using Maximum Basking Observations as the response variable with site type (Road vs. No Road), road density and total traffic volume as predictor variables. None of site type, road density or total traffic was significantly related to Maximum Basking Observations (Appendix D). As a second set of post-hoc analyses, I evaluated the relationship between In-water Observations and the Observability index. Unlike Basking Observations, visible water depth must be accounted for when using In-water Observations as the response variable; therefore I conducted a simple linear regression of the Observability index on In-water Observations. Surprisingly, Observability was not significantly related to In-water Observations (Appendix E). I therefore omitted the Observability index from further analyses using In-water Observations and conducted 
three simple linear regressions using In-water Observations as the response variable with site type, road density and total traffic volume as predictor variables. Once again, none of the road associated predictor variables was significantly related to my measure of relative painted turtle abundance, In-water Observations (Appendix E). The results of these posthoc analyses, all of which show no significant effects of roads on painted turtle relative abundance, lend support to my previous conclusion that roads do not have a negative effect on the sampled painted turtle populations.

While I did make an effort through site selection (by selecting only those ponds that were a minimum of $250 \mathrm{~m}$ from any other water source; Table 1) to limit immigration potential to my ponds, painted turtles have been shown on rare occasions to move much greater distances over land (>1 km; Bowne and White 2004, Caldwell and Nams 2006). It is therefore possible that I was unable to detect a negative effect of roads on turtle relative abundance even though one was present because the negative effect was being masked by immigrating individuals. Most painted turtle over-land movements are short distances averaging less than $200 \mathrm{~m}$ from the pond (Christens and Bider 1987, Burke and Gibbons 1995, Rowe 2003, Baldwin et al. 2004, Caldwell and Nams 2006), so by selecting only those ponds that were a minimum of $250 \mathrm{~m}$ from any other water source (with most being much further; mean distance to nearest waterbody $=372 \mathrm{~m}$; Table 1), frequent immigration seems unlikely. However unlikely, I cannot entirely rule out the possibility that immigration is masking the negative effect of roads on the sampled painted turtle populations.

Finally, it is possible that road mortality can negatively affect painted turtle populations but that this did not occur due to the high traffic volume on the roads 
included in this study. As part of my study design, I selected ponds for Road sites that were as close as possible to very high traffic roads (Table 1) on the assumption that the more traffic a road has, the less likely it would be that a turtle attempting to cross would survive (Aresco 2005b); thus high traffic roads directly adjacent to turtle populations should equate to very high rates of road mortality. There is the possibility however that very high traffic roads may simply act as movement barriers without significant mortality. In other words, turtles may not even attempt to cross the roads due to the constant heavy volume of traffic. Note however, that this is purely conjectural as painted turtles have not been shown to avoid roads (e.g.: Baldwin et al. 2004). It is therefore unlikely that I did not detect a negative effect of roads on painted turtle relative abundance because of the very high traffic volume on roads close to my Road sites.

The other possible explanation for why I did not observe a relationship between the presence of high traffic roads and painted turtle relative abundance in this study is perhaps because no such relationship exists. There may be one or more compensatory positive road effects that are counter-balancing or reducing any negative effects of road mortality such that there is no net negative effect of roads on turtle populations. For example, as mentioned previously, turtles experience very high mortality rates as eggs or young in the nest, much of this due to nest predation by species such as racoons (Procyon lotor) and foxes (Vulpes vulpes) (Wilbur 1975, Tinkle et al. 1981, Christens and Bider 1987, Mitchell 1988, Aresco 2004): Studies have found reduced predation of turtle nests farther from the pond edge (Christens and Bider 1987, Kolbe and Janzen 2002, Marchand et al. 2002, Baldwin et al. 2004) and closer to road edges (Marchand and Litvaitis 2004b). In addition, numerous studies have shown that predator species are susceptible to the 
negative impacts of roads (reviewed in Fahrig and Rytwinski 2009). It is therefore possible that the negative effect of road mortality on turtles is outweighed by the positive impact of predator release on eggs and young thus increasing the overall recruitment into the population.

Increased recruitment into populations close to high traffic roads would presumable lead to a smaller average body size in turtle populations at Roads sites compared to No Road sites. Puzzlingly however, females were found to be, on average, significantly larger at Roads sites while males had the same average body size at Road and No Road sites (Figure 7). Roe et al. (2011) compared turtle populations in a suburban landscape and in an adjacent nature preserve and found that populations in the disturbed suburban areas were primarily composed of larger individuals, although they found this trend to be true in both males and females. They found that adult turtles in the suburban population exhibited much higher growth rates than those found in the nearby nature reserve, likely explaining the observed difference in overall body size. While they do not provide conclusive reasoning for the observed difference in body size and growth rate between the suburban and nature preserve populations, they suggest that the more disturbed suburban site may have increased nutrient loads thus somehow provide access to more food resulting in increased growth rates (Roe et al. 2011). It seems unlikely however that the larger average body size observed at Road sites in the current study was a result of differential growth rates between site types as Road and No Road sites did not differ significantly in local or landscape scale habitat variables and the difference in average body size was only observed in females. I suggest that a yet-to-be-determined factor, somehow related to nesting behaviour (a behaviour that is exclusive to females in 
painted turtles), is likely responsible for causing this significant size differential in females between Road and No Road sites.

It is also possible that rapid evolution has occurred in turtle populations at Road sites, therefore eliminating the negative effect of road mortality on the populations. If road mortality is high in a particular area and all turtles that attempt to nest close to roads or cross roads are killed, then over time this should eventually lead to natural selection against individuals undertaking overland movements at sites close to high traffic roads. Janzen and Morjan (2001) looked at repeatability in micro-environment-based nest site choice in female painted turtles and suggest that certain aspects of painted turtle nesting behaviour may indeed be subject to microevolution. Temple (1987) found that significantly more females were nesting away from ecological edges, such as the edge of a wooded area where nest predation was higher, than would be expected if they were nesting randomly within the landscape, suggesting that selection may favour females that nest further from ecological edges. It is therefore possible that selective pressures from road mortality have favoured females that nest close to ponds at sites close to high traffic roads resulting in reduced road mortality and less potential for population decline. This is somewhat speculative however as I am unaware of the actual over-land movement patterns of the turtles in the sampled populations.

One possible way to test this hypothesis would be to conduct a radio-telemetry study similar to the one described in Row et al. (2007). By tracking more than one hundred individual black ratsnakes (Elaphe obsoleta) over a period of eight years they were able to estimate percent annual road mortality for the population and use this value in a population viability analysis to determine the impact of road mortality on the 
probability of population persistence. The Row et al. (2007) telemetry study was however, conducted on a single population near a secondary road, which would not be sufficient for comparing estimated population viability of turtle populations at multiple sites close to and far from high traffic roads. If however, the same methods were applied to several turtle populations the direct impacts of road mortality on painted turtle populations could perhaps be determined with greater accuracy. Baldwin et al. (2004) conducted a radio telemetry study looking at over-land movements made by painted turtles in three ponds with varying road density in the surrounding landscape. While they did observe road mortality of some of their transmitter equipped turtles, their study did not focus on determining the impacts of roads on population viability, so does not make assumptions about whether or not the observed road mortality could potentially reduce overall population size.

In addition to finding no significant relationship between painted turtle relative abundance and high traffic roads, I did not find the predicted male-biased sex-ratio at Road sites. This finding tends to support the interpretation that there is no negative effect of roads on the sampled populations rather than a road effect that was simply not detected through comparisons of relative painted turtle abundance.

\section{Conclusions and mitigation implications}

Road mortality is thought to be a leading cause of adult mortality in turtles, a species that is especially susceptible to population decline with increased adult mortality due to life history traits (Gibbs and Shriver 2002, Bulté et al. 2010). Road mortality was therefore predicted to have a strong negative impact on painted turtle populations. Contrary to what I expected however, my results suggest that high traffic roads, and thus 
presumably elevated road mortality, do not negatively affect the sampled painted turtle populations.

I cannot generalize my results however to say that road mortality does not ever negatively affect turtle populations. First, populations of other turtle species may be more susceptible to road mortality than are painted turtles. Gibbs and Shriver (2002) found in their modelling study that although populations of small-bodied pond turtles were unlikely to be negatively affected by road networks, large-bodied pond turtle and terrestrial turtles could potentially show population declines as a result of increased road density and traffic volume. This is likely because land based species and large-bodied pond turtles are known to move more frequently over land and cover greater distances than small-bodied pond turtles, thus increasing their chances of road mortality (Gibbs and Shriver 2002). In addition, there are certain situations in which road mortality is so high that population decline seems inevitable. Wood and Herlands (1997) studied a population of Northern Diamondback Terrapins (Malaclemys terrapin terrapin) in which female turtles are forced to migrate annually over land in search of suitable nesting sites as human developments have significantly reduced the suitable habitat in the area immediately surrounding the population's primary habitat. They incubated eggs from road-killed females and reared the hatchlings for several months before releasing them back into the population. However even with these intensive efforts, they were not able to successfully replace individuals into the population as quickly as they were being removed due to road mortality. Aresco (2003) looked at the impacts of U.S. Highway 27 on several herpetofaunal species, including ten species of turtles. Construction of the highway, which bisects Lake Jackson, resulted in the creation of Little Lake Jackson, a 
small arm of the original lake. Lake Jackson is prone to drying and when drought occurs, the turtle populations from Lake Jackson undergo mass migration across Highway 27 to Little Lake Jackson. This migration represents the largest turtle migration on record with more than 1200 turtles attempting to cross Highway 27 per km per year, and with only a $2 \%$ chance of successfully crossing (Aresco 2003); population decline in the long-run seems inevitable.

In contrast to those examples, my study considered ponds where it is unlikely that turtles are forced to migrate over roads. My results suggest that road mitigation for turtles, at least painted turtles, may not be necessary in some cases. However there are clearly circumstances in which road mortality of turtles poses a distinct threat to the persistence of the population because of forced over-land migration across high traffic roads. It is at such sites that mitigation efforts for painted turtles should be focussed. 


\section{Works Cited}

Aresco, M. J. 2003. Highway mortality of turtles and other herpetofauna at Lake Jackson, Florida, USA, and the efficacy of a temporary fence/culvert system to reduce roadkills. Pages 433-449 in C. L. Irwin, P. Garrett, and K. P. McDermott, editors. Proceedings of the International Conference on Ecology and Transportation, Center for Transportation and the Environment, North Carolina State University, Raleigh, North Carolina.

Aresco, M. J. 2004. Reproductive Ecology of Pseudemys floridana and Trachemys scripta (Testudines: Emydidae) in Northwestern Florida. Journal of Herpetology 38:249-256.

Aresco, M. J. 2005a. The effect of sex-specific terrestrial movements and roads on the sex ratio of freshwater turtles. Biological Conservation 123:37-44.

Aresco, M. J. 2005b. Mitigation measures to reduce highway mortality of turtles and other herpetofauna at a north Florida lake. Joumal of Wildlife Management 69:549-560.

Ashley, E. P., and J. T. Robinson. 1996. Road mortality of amphibians, reptiles and other wildlife on the Long Point Causeway, Lake Erie, Ontario. Canadian Field Naturalist 110:403-412.

Baldwin, E. A., M. N. Marchand, and J. A. Litvaitis. 2004. Terrestrial habitat use by nesting painted turtles in landscapes with different levels of fragmentation. Northeastern Naturalist 11:41-48.

Beaudry, F., P. G. deMaynadier, and M. L. Hunter Jr. 2008. Identifying road mortality threat at multiple spatial scales for semi-aquatic turtles. Biological Conservation 141:2550-2563.

Bowne, D. R., and H. R. White. 2004. Searching strategy of the painted turtle Chrysemys picta across spatial scales. Animal Behaviour 68:1401-1409.

Bradford, L. 2003. Road mortality effects on the turtle population at St. Lawrence Islands National Park. Pages 443-447 in Parks Research Forum of Ontario 2003 Proceedings. Centre for Applied Science in Ontario Protected Areas, University of Waterloo, Waterloo, Ontario.

Bulté, G., and G. Blouin-Demers. 2009. Does Sexual Bimaturation Affect the Cost of Growth and the Operational Sex Ratio in an Extremely Size-Dimorphic Reptile? Ecoscience 16:175-182. 
Bulté, G., M. A. Carrière, and G. Blouin-Demers. 2010. Impact of recreational power boating on two populations of northern map turtles (Graptemys geographica). Aquatic Conservation: Marine and Freshwater Ecosystems 20:31-38.

Burke, V. J., and J. W. Gibbons. 1995. Terrestrial Buffer Zones and Wetland Conservation: A Case Study of Freshwater Turtles in a Carolina Bay. Conservation Biology 9:1365-1369.

Bury, R. B. 2011. Modifications of Traps to Reduce Bycatch of Freshwater Turtles. Journal of Wildlife Management 75:3-5.

Bury, R. B., and D. J. Germano. 2003. Differences in Habitat Use by Blanding's Turtles, Emydoidea blandingii, and Painted Turtles, Chysemys picta, in the Nebraska Sandhills. American Midland Naturalist 149:241-244.

Caldwell, I. R., and V. O. Nams. 2006. A compass without a map: tortuosity and orientation of eastern painted turtles (Chrysemys picta picta) released in unfamiliar territory. Canadian Journal of Zoology 84:1129.

Christens, E., and J. R. Bider. 1987. Nesting Activity and Hatching Success of the Painted Turtle (Chrysemys picta marginata) in Southwestern Québec. Herpetologica 43:55-65.

Congdon, J. D., and J. W. Gibbons. 1996. Structure and dynamics of a turtle community over two decades. Pages 137-159 in M. C. Cody and J. Smallwood, editors. LongTerm Studies of Vertebrate Communities. Academic Press, New York.

Congdon, J. D., R. D. Nagle, O. M. Kinney, R. C. van Loben Sels, T. Quinter, and D. W. Tinkle. 2003. Testing hypotheses of aging in long-lived painted turtles (Chrysemys picta). Experimental Gerontology 38:765-772.

Dorcas, M. E., J. D. Willson, and J. W. Gibbons. 2007. Crab trapping causes population decline and demographic changes in diamondback terrapins over two decades. Biological Conservation 137:334-340.

Eigenbrod, F., S. J. Hecnar, and L. Fahrig. 2008. The relative effects of road traffic and forest cover on anuran populations. Biological Conservation 141:35-46.

Ernst, C. H. 1971. Population Dynamics and Activity Cycles of Chrysemys picta in Southeastern Pennsylvania. Journal of Herpetology 5:151-160.

Emst, C. H., and J. E. Lovich. 2009. Turtles of the United States and Canada. Second edition. Johns Hopkins University Press, Baltimore, Maryland.

Ewert, M. A., and C. E. Nelson. 1991. Sex Determination in Turtles: Diverse Patterns and Some Possible Adaptive Values. Copeia 1991:50-69. 
Fahrig, L., and T. Rytwinski. 2009. Effects of roads on animal abundance: An empirical review and synthesis. Ecology and Society 14:21.

Findlay, C. S., and J. Bourdages. 2000. Response Time of Wetland Biodiversity to Road Construction on Adjacent Lands. Conservation Biology 14:86-94.

Findlay, C. S., and J. Houlahan. 1997. Anthropogenic Correlates of Species Richness in Southeastern Ontario Wetlands. Conservation Biology 11:1000-1009.

Frazer, N. B., J. L. Greene, and J. W. Gibbons. 1993. Temporal Variation in Growth Rate and Age at Maturity of Male Painted Turtles, Chrysemys picta. American Midland Naturalist 130:314-324.

Galois, P., and M. Ouellet. 2007. Traumatic Injuries in Eastern Spiny Softshell Turtles (Apalone spinifera) Due to Recreational Activities in the Northern Lake Champlain Basin. Chelonian Conservation and Biology 6:288-293.

Garber, S. D., and J. Burger. 1995. A 20-Yr Study Documenting the Relationship Between Turtle Decline and Human Recreation. Ecological Applications 5:11511162.

Gibbons, J. W. 1968. Population Structure and Survivorship in the Painted Turtle, Chrysemys picta. Copeia 1968:260-268.

Gibbons, J. W., D. E. Scott, T. J. Ryan, K. A. Buhlmann, T. D. Tuberville, B. S. Metts, J. L. Greene, T. Mills, Y. Leiden, S. Poppy, and C. T. Winne. 2000. The Global Decline of Reptiles, Déjà Vu Amphibians. BioScience 50:653-666.

Gibbs, J. P., and W. G. Shriver. 2002. Estimating the Effects of Road Mortality on Turtle Populations. Conservation Biology 16:1647-1652.

Gibbs, J. P., and D. A. Steen. 2005. Trends in Sex Ratios of Turtles in the United States: Implications of Road Mortality. Conservation Biology 19:552-556.

Government of Canada. 2011. Species at Risk Public Registry. Accessed March, 2012, from http://www.sararegistry.gc.ca.

Gutzke, W. H. N., and G. L. Paukstis. 1984. A Low Threshold Temperature for Sexual Differentiation in the Painted Turtle, Chrysemys picta. Copeia 1984:546-547.

Janzen, F. J., and C. L. Morjan. 2001. Repeatability of microenvironment-specific nesting behaviour in a turtle with environmental sex determination. Animal Behaviour 62:73-82. 
Kolbe, J. J., and F. J. Janzen. 2002. Spatial and temporal dynamics of turtle nest predation: edge effects. Oikos 99:538-544.

Krawchuk, M. A., and R. J. Brooks. 1998. Basking Behavior as a Measure of Reproductive Cost and Energy Allocation in the Painted Turtle, Chrysemys picta. Herpetologica 54:112-121.

Larocque, S. M., A. H. Colotelo, S. J. Cooke, G. Blouin-Demers, T. Haxton, and K. E. Smokorowski. 2012. Seasonal patterns in bycatch composition and mortality associated with a freshwater hoop net fishery. Animal Conservation 15:53-60.

Lefevre, K., and R. J. Brooks. 1995. Effects of Sex and Body Size on Basking Behavior in a Northern Population of the Painted Turtle, Chrysemys picta. Herpetologica 51:217-224.

Mahmoud, I. Y. 1968. Nesting Behavior in the Western Painted Turtle, chrysemys Picta bellii. Herpetologica 24:158-162.

Marchand, M. N., and J. A. Litvaitis. 2004a. Effects of Habitat Features and Landscape Composition on the Population Structure of a Common Aquatic Turtle in a Region Undergoing Rapid Development. Conservation Biology 18:758-767.

Marchand, M. N., and J. A. Litvaitis. 2004b. Effects of landscape composition, habitat features, and nest distribution on predation rates of simulated turtle nests. Biological Conservation 117:243-251.

Marchand, M. N., J. A. Litvaitis, T. J. Maier, and R. M. DeGraaf. 2002. Use of Artificial Nests to Investigate Predation on Freshwater Turtle Nests. Wildlife Society Bulletin 30:1092-1098.

Mitchell, J. C. 1988. Population Ecology and Life Histories of the Freshwater Turtles Chrysemys picta and Sternotherus odoratus in an Urban Lake. Herpetological Monographs 2:40-61.

Moll, E. O. 1973. Latitudinal and Intersubspecific Variation in Reproduction of the Painted Turtle, Chrysemys picta. Herpetologica 29:307-318.

Ontario Ministry of Natural Resources. 2007.Built-up Area [computer file]. Available: Carleton University Maps, Data and Government Information Centre controlled access DATA PC J:IOntariolMinistry_of_Natural_Resources\Thematic_Dataleast.

Ontario Ministry of Natural Resources. 2009. Digital Raster Acquisition Project Eastern Ontario [computer file]. Peterborough, Ontario: Available: Carleton University Maps, Data and Government Information Centre controlled access DATA PC J:IOntariolMinistry_of_Natural_Resources\DRAPE2008\DRAPE2008-1km. 
Ontario Ministry of Natural Resources. 2010a. Ontario Road Network Segment With Address [computer file]. Available: Carleton University Maps, Data and Government Information Centre controlled access DATA PC J:IOntariolMinistry_of_Natural_Resources\Thematic_Dataleast.

Ontario Ministry of Natural Resources. 2010b. Wooded Area [computer file]. Available: Carleton University Maps, Data and Government Information Centre controlled access DATA PC J:IOntariolMinistry_of_Natural_Resources \Thematic_Dataleast.

Ontario Ministry of Transportation. 2008. Ontario Provincial Highways Traffic Volume On Demand. Accessed February, 2011, from http://www.raqsb.mto.gov.on.ca/techpubs/TrafficVolumes.nsf/tvweb.

Roe, J. H., M. Rees, and A. Georges. 2011. Suburbs: Dangers or Drought Refugia for Freshwater Turtle Populations? Journal of Wildlife Management 75:1544-1552.

Row, J. R., G. Blouin-Demers, and P. J. Weatherhead. 2007. Demographic effects of road mortality in black ratsnakes (Elaphe obsoleta). Biological Conservation 137:117124.

Rowe, J. W. 2003. Activity and Movements of Midland Painted Turtles (Chrysemys picta marginata) Living in a Small Marsh System on Beaver Island, Michigan. Journal of Herpetology 37:342-353.

Schlaepfer, M. A., C. Hoover, and C. K. Dodd. 2005. Challenges in Evaluating the Impact of the Trade in Amphibians and Reptiles on Wild Populations. BioScience 55:256-264.

Shine, R., and J. B. Iverson. 1995. Patterns of Survival, Growth and Maturation in Turtles. Oikos 72:343-348.

Snow, J. E. 1980. Second Clutch Laying by Painted Turtles. Copeia 1980:534-536.

Steen, D. A., M. J. Aresco, S. G. Beilke, B. W. Compton, E. P. Condon, C. Kenneth Dodd, H. Forrester, J. W. Gibbons, J. L. Greene, G. Johnson, T. A. Langen, M. J. Oldham, D. N. Oxier, R. A. Saumure, F. W. Schueler, J. M. Sleeman, L. L. Smith, J. K. Tucker, and J. P. Gibbs. 2006. Relative vulnerability of female turtles to road mortality. Animal Conservation 9:269-273.

Steen, D. A., and J. P. Gibbs. 2004. Effects of Roads on the Structure of Freshwater Turtle Populations. Conservation Biology 18:1143-1148.

Temple, S. A. 1987. Predation on Turtle Nests Increases near Ecological Edges. Copeia 1987:250-252. 
Tinkle, D. W., J. D. Congdon, and P. C. Rosen. 1981. Nesting Frequency and Success: Implications for the Demography of Painted Turtles. Ecology 62:1426-1432.

Wilbur, H. M. 1975. The Evolutionary and Mathematical Demography of the Turtle Chrysemys picta. Ecology 56:64-77.

Wood, R. C., and R. Herlands. 1997. Turtles and Tires: The Impact of Roadkills on Northern Diamondback Terrapin, Malaclemys terrapin terrapin, Populations on the Cape May Peninsula, Southern New Jersey, USA. Pages 46-53 in Proceedings: Conservation, Restoration, and Management of Tortoises and Turtles - An International Conference. The New York Turtle and Tortoise Society, Purchase, New York. 
Table 1. Summary of pond size and surrounding area at each Road (R) and No Road (NR) site. Road age applies to the high traffic road at each Road site and total traffic volume (total AADT) is the Average Annual Daily Traffic (AADT) on each road multiplied by the total length of the road within a $300 \mathrm{~m}$ radius of each pond. Percent forest cover, crop cover and urban area are measured within a $300 \mathrm{~m}$ radius of the pond.

\begin{tabular}{|c|c|c|c|c|c|c|c|c|c|c|}
\hline Site & $\begin{array}{c}\text { Perimeter } \\
\text { (m) }\end{array}$ & $\begin{array}{c}\text { Area } \\
\left(\mathrm{m}^{2}\right)\end{array}$ & $\begin{array}{c}\text { Pond age } \\
\text { (yrs) }\end{array}$ & $\begin{array}{c}\text { Road age } \\
\text { (yrs) }\end{array}$ & $\begin{array}{l}\text { Nearest major } \\
\quad \operatorname{road}(\mathbf{m})\end{array}$ & $\begin{array}{c}\text { Total } \\
\text { AADT }\end{array}$ & $\begin{array}{l}\% \text { forest } \\
\text { cover }\end{array}$ & $\begin{array}{l}\% \text { crop } \\
\text { cover }\end{array}$ & $\begin{array}{c}\% \text { urban } \\
\text { area }\end{array}$ & $\begin{array}{l}\text { Nearest body } \\
\text { of water }(\mathrm{m})\end{array}$ \\
\hline$\overline{\mathrm{Rl}}$ & 377.8 & 5298.8 & 43 & 51 & 85 & 79146.9 & 0.1 & 0 & 66.2 & 320 \\
\hline $\mathrm{R} 2$ & 845.5 & 13425.0 & 48 & 48 & 55 & 10848.1 & 45.5 & 7.6 & 0 & 465 \\
\hline R3 & 389.1 & 4614.3 & 43 & 90 & 65 & 5362.7 & 20.7 & 15.5 & 0 & 330 \\
\hline $\mathrm{R} 4$ & 575.8 & 19878 & 48 & 48 & 62 & 22104.2 & 15.6 & 33.6 & 0 & 490 \\
\hline $\mathrm{R} 5$ & 323.3 & 7229.0 & 48 & 48 & 50 & 17977.5 & 16.2 & 4.0 & 0.1 & 290 \\
\hline R6 & 173.1 & 1035.0 & 47 & 50 & 10 & 4126.9 & 34.5 & 35.8 & 0 & 350 \\
\hline $\mathrm{R} 7$ & 298.8 & 4111.0 & 50 & 50 & 50 & 5559.6 & 30.7 & 24.9 & 0 & 475 \\
\hline $\mathrm{R} 8$ & 472.3 & 3862.2 & 45 & 38 & 57 & 31383.9 & 23.4 & 29.2 & 0 & 260 \\
\hline R9 & 244.8 & 2720.3 & 43 & 73 & 120 & 3421.3 & 49.8 & 20.2 & 3.8 & 265 \\
\hline $\mathrm{R} 10$ & 231.3 & 3244.2 & 43 & 50 & 100 & 4990.7 & 58.5 & 0 & 4.4 & 370 \\
\hline Mean & 393.2 & 6541.7 & 46 & 55 & 65 & 18492.2 & 29.5 & 17.1 & 7.5 & 362 \\
\hline NR1 & 601.6 & 14200.0 & 52 & - & 3200 & 139.8 & 55.9 & 14.2 & 0 & 320 \\
\hline NR2 & 244.7 & 3773.0 & 30 & - & 1600 & 8.5 & 43.4 & 12.8 & 0 & 250 \\
\hline NR3 & 291.1 & 6070.4 & 35 & - & 945 & 0 & 66.7 & 19.8 & 0 & 440 \\
\hline NR4 & 508.5 & 7536.5 & 48 & - & 980 & 240.4 & 2.8 & 59.8 & 0 & 250 \\
\hline NR5 & 252.6 & 1759.5 & 80 & - & 465 & 311.8 & 7.8 & 53.1 & 2.1 & 295 \\
\hline NR6 & 88.5 & 553.4 & 42 & - & 2030 & 85.9 & 22.4 & 55.4 & 0 & 690 \\
\hline NR7 & 827.2 & 10666.0 & 44 & - & 2500 & 0 & 76.0 & 0 & 0 & 605 \\
\hline NR8 & 332.7 & 4148.9 & 25 & - & 300 & 195.9 & 56.5 & 2.9 & 11.5 & 365 \\
\hline NR9 & 462.8 & 11221.0 & 75 & - & 1700 & 0 & 41.1 & 13.4 & 0 & 280 \\
\hline NR10 & 219.2 & 2237.8 & 90 & - & 1450 & 140.8 & 37.7 & 27.6 & 0 & 320 \\
\hline Mean & 382.9 & 6216.7 & 52 & - & 1517 & 112.3 & 41.1 & 25.2 & 1.4 & 382 \\
\hline
\end{tabular}


Table 2. Results of t-tests comparing local and landscape variables at Road and No Road sites. Variables (a) - (d) were estimated within a $5 \mathrm{~m}$ radius of the pond edge, variables (e) $-(j)$ were estimated at the surface of each pond and variables $(k)-(m)$ were estimated within a $300 \mathrm{~m}$ radius of each pond.

\begin{tabular}{|c|c|c|c|c|c|c|c|}
\hline & Variable & Site Type & Mean & SE & t & df & $\mathbf{p}$ \\
\hline (a) & $\%$ Forest cover & $\begin{array}{l}\text { Road } \\
\text { No Road }\end{array}$ & $\begin{array}{l}36.0 \\
53.7\end{array}$ & $\begin{array}{c}10.2 \\
9.4\end{array}$ & 1.27 & 18 & 0.218 \\
\hline (b) & $\%$ Grass cover & $\begin{array}{l}\text { Road } \\
\text { No Road }\end{array}$ & $\begin{array}{l}33.3 \\
35.8 \\
\end{array}$ & $\begin{array}{l}10.5 \\
11.0 \\
\end{array}$ & -0.967 & 18 & 0.346 \\
\hline (c) & $\%$ Shrub cover & $\begin{array}{l}\text { Road } \\
\text { No Road }\end{array}$ & $\begin{array}{l}12.5 \\
10.5 \\
\end{array}$ & $\begin{array}{l}7.8 \\
4.9 \\
\end{array}$ & -0.219 & 18 & 0.829 \\
\hline (d) & $\%$ Open ground & $\begin{array}{l}\text { Road } \\
\text { No Road }\end{array}$ & $\begin{array}{l}1.0 \\
0.0\end{array}$ & $\begin{array}{l}0.7 \\
0.0\end{array}$ & -1.5 & 9 & 0.168 \\
\hline (e) & $\%$ Open water & $\begin{array}{l}\text { Road } \\
\text { No Road }\end{array}$ & $\begin{array}{l}81.3 \\
87.9 \\
\end{array}$ & $\begin{array}{l}4.3 \\
2.4 \\
\end{array}$ & 1.356 & 18 & 0.192 \\
\hline (f) & $\%$ Emergent vegetation & $\begin{array}{l}\text { Road } \\
\text { No Road }\end{array}$ & $\begin{array}{l}7.5 \\
7.7\end{array}$ & $\begin{array}{l}1.7 \\
2.1\end{array}$ & 0.075 & 18 & 0.941 \\
\hline (g) & $\begin{array}{l}\text { \% Submerged aquatic } \\
\text { vegetation }\end{array}$ & $\begin{array}{l}\text { Road } \\
\text { No Road }\end{array}$ & $\begin{array}{l}11.2 \\
4.4\end{array}$ & $\begin{array}{l}3.7 \\
1.5 \\
\end{array}$ & -1.686 & 12 & 0.118 \\
\hline (h). & Mean $\mathrm{pH}$ & $\begin{array}{l}\text { Road } \\
\text { No Road }\end{array}$ & $\begin{array}{l}9.5 \\
9.0\end{array}$ & $\begin{array}{l}0.2 \\
0.2\end{array}$ & -1.603 & 18 & 0.126 \\
\hline (i) & Mean temperature & $\begin{array}{l}\text { Road } \\
\text { No Road }\end{array}$ & $\begin{array}{l}25.5 \\
25.9\end{array}$ & $\begin{array}{l}0.4 \\
0.5\end{array}$ & 0.582 & 18 & 0.568 \\
\hline (j) & Mean conductivity & $\begin{array}{l}\text { Road } \\
\text { No Road }\end{array}$ & $\begin{array}{l}656.8 \\
290.5 \\
\end{array}$ & $\begin{array}{c}214.2 \\
81.1\end{array}$ & -1.6 & 18 & 0.127 \\
\hline (k) & $\%$ Forest cover & $\begin{array}{l}\text { Road } \\
\text { No Road }\end{array}$ & $\begin{array}{l}29.5 \\
41.0\end{array}$ & $\begin{array}{l}5.7 \\
7.7\end{array}$ & 1.212 & 18 & 0.241 \\
\hline (l) & $\%$ Crop cover & $\begin{array}{l}\text { Road } \\
\text { No Road }\end{array}$ & $\begin{array}{l}17.1 \\
25.9\end{array}$ & $\begin{array}{l}4.3 \\
7.0\end{array}$ & 1.068 & 18 & 0.300 \\
\hline (m) & $\%$ Urban area & $\begin{array}{l}\text { Road } \\
\text { No Road }\end{array}$ & $\begin{array}{l}7.5 \\
1.4\end{array}$ & $\begin{array}{l}6.6 \\
1.1\end{array}$ & -0.917 & 18 & 0.371 \\
\hline (n) & $\begin{array}{l}\text { Distance to nearest boc } \\
\text { of water }(\mathrm{m})\end{array}$ & $\begin{array}{l}\text { Road } \\
\text { No Road }\end{array}$ & $\begin{array}{l}362.0 \\
382.0\end{array}$ & $\begin{array}{l}27.4 \\
48.2\end{array}$ & -0.361 & 18 & 0.722 \\
\hline
\end{tabular}


Table 3. Results of simple linear regressions using square root-transformed Turtle Observations as the response variable. Predictor variables (a) - (d) were estimated within a $5 \mathrm{~m}$ radius of the pond edge, variables (e) - (j) were estimated at the surface of each pond and variables $(k)-(m)$ were estimated within a 300 m radius of each pond.

\begin{tabular}{|c|c|c|c|c|c|c|}
\hline & Predictor variable & $\mathbf{R}^{2}$ & $\beta$ & $\mathbf{F}$ & df & $\mathbf{p}$ \\
\hline (a) & $\%$ Forest cover & $<0.001$ & 0.011 & 0.002 & 1,18 & 0.963 \\
\hline (b) & $\%$ Grass cover & 0.003 & 0.056 & 0.056 & 1,18 & 0.815 \\
\hline (c) & $\%$ Shrub cover & 0.012 & -0.107 & 0.21 & 1,18 & 0.652 \\
\hline (d) & $\%$ Open ground cover & 0.004 & -0.065 & 0.076 & 1,18 & 0.785 \\
\hline (e) & $\%$ Open water & 0.005 & 0.068 & 0.083 & 1,18 & 0.776 \\
\hline (f) & $\%$ Emergent vegetation & 0.117 & 0.342 & 2.392 & 1,18 & 0.139 \\
\hline (g) & $\%$ Submerged aquatic vegetation & 0.085 & -0.292 & 1.675 & 1,18 & 0.212 \\
\hline (h) & Mean $\mathrm{pH}$ & 0.039 & -0.198 & 0.734 & 1,18 & 0.403 \\
\hline (i) & Mean temperature & 0.01 & 0.098 & 0.174 & 1,18 & 0.681 \\
\hline (j) & Mean conductivity & 0.142 & -0.376 & 2.967 & 1,18 & 0.102 \\
\hline (k) & $\%$ Forest cover & 0.115 & 0.339 & 2.341 & 1,18 & 0.143 \\
\hline (1) & $\%$ Crop cover & 0.143 & -0.379 & 3.013 & 1,18 & 0.100 \\
\hline (m) & $\%$ Urban area & 0.055 & -0.235 & 1.053 & 1,18 & 0.318 \\
\hline (n) & Distance to nearest waterbody (m) & 0.001 & 0.035 & 0.022 & 1,18 & 0.884 \\
\hline
\end{tabular}


Table 4. Results of three multiple linear regressions using square root transformed Turtle Observations as the response variable and (a) Observability index and site type (Road vs. No Road, where Road $=1$ and No Road $=0$ ), (b) Observability index and road density and (c) Observability index and total traffic volume (total AADT) as predictor variables.

\begin{tabular}{|c|c|c|c|c|c|}
\hline & Source & df & $\mathbf{F}$ & $\boldsymbol{\beta}$ & $\mathbf{p}$ \\
\hline \multirow{4}{*}{ (a) } & Corrected model & 2,17 & 6.067 & - & 0.010 \\
\hline & Observability index & 1 & 12.07 & 0.498 & 0.003 \\
\hline & Site type & 1 & 0.171 & 0.178 & 0.685 \\
\hline & $R^{2}=0.416$ & & & & \\
\hline \multirow{4}{*}{ (b) } & Corrected model & 2,17 & 6.134 & - & 0.010 \\
\hline & Observability index & 1 & 11.883 & 0.638 & 0.003 \\
\hline & Road density & 1 & 0.250 & -0.092 & 0.623 \\
\hline & $R^{2}=0.419$ & & & & \\
\hline \multirow{4}{*}{ (c) } & Corrected model & 2,17 & 5.928 & - & 0.011 \\
\hline & Observability index & 1 & 11.341 & 0.638 & 0.004 \\
\hline & Total AADT & 1 & 0.007 & -0.016 & 0.934 \\
\hline & $R^{2}=0.411$ & & & & \\
\hline
\end{tabular}




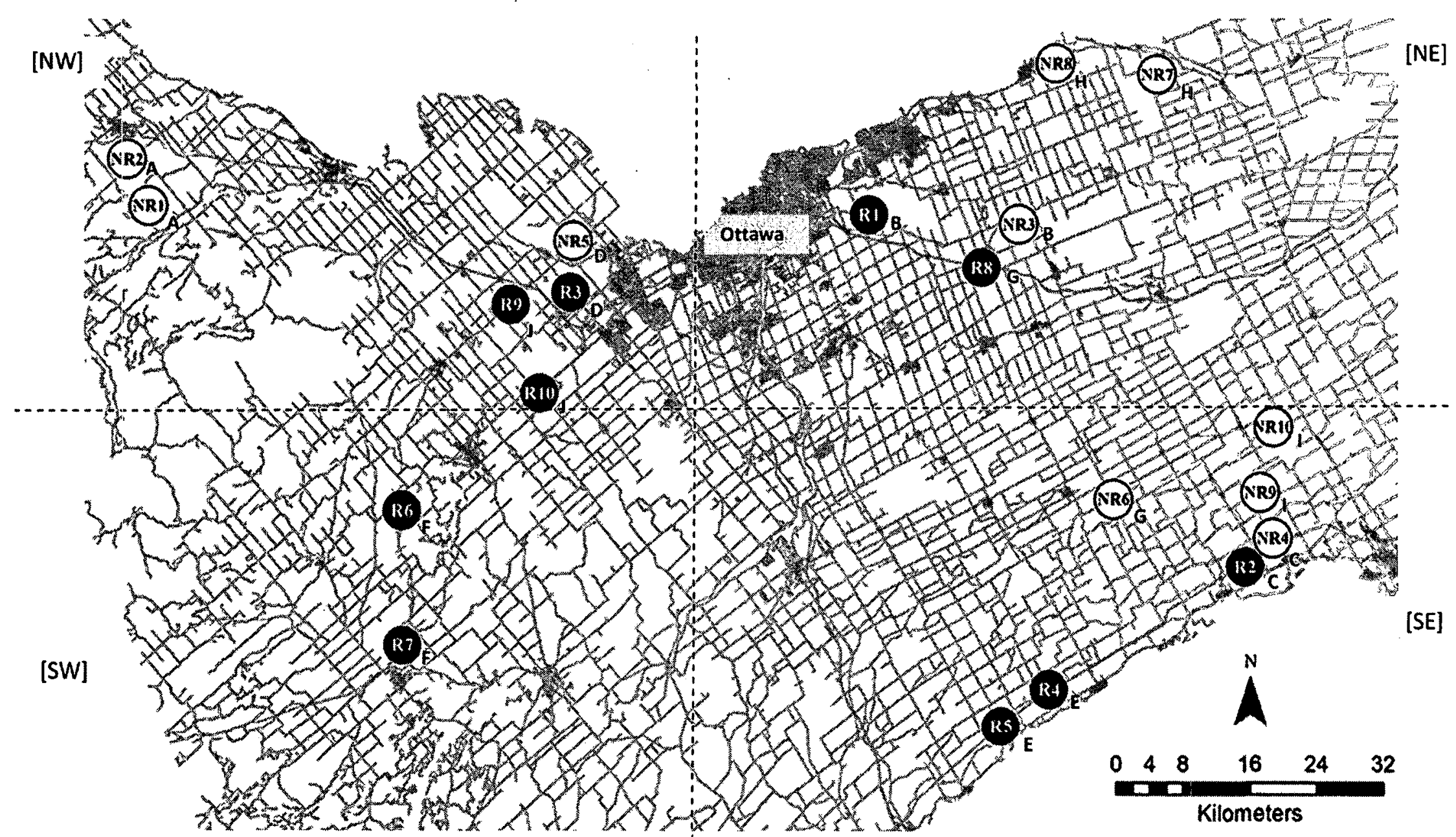

Figure 1. Distribution of the 20 ponds ( 10 Road $(\bullet ; R)$ and 10 No Road $(\mathbf{0} ; N R)$ sites) sampled across eastern Ontario from June $1^{\text {st }}$ to August $28^{\text {th }}, 2011$. Ponds were paired based on geographic proximity, with the exception of one pair that was separated by a relatively large distance compared to the other pairs (pair $G$ ). Paired sites share the same capitol letter $(A-H)$, based on the order in which they were sampled, beginning with pair A. The study region was divided into four areas: north-east [NE], south-east [SE], south-west [SW] and north-west [NW], shown by the dashed lines, with one pair of ponds from each area being sampled in a rotational manner. 


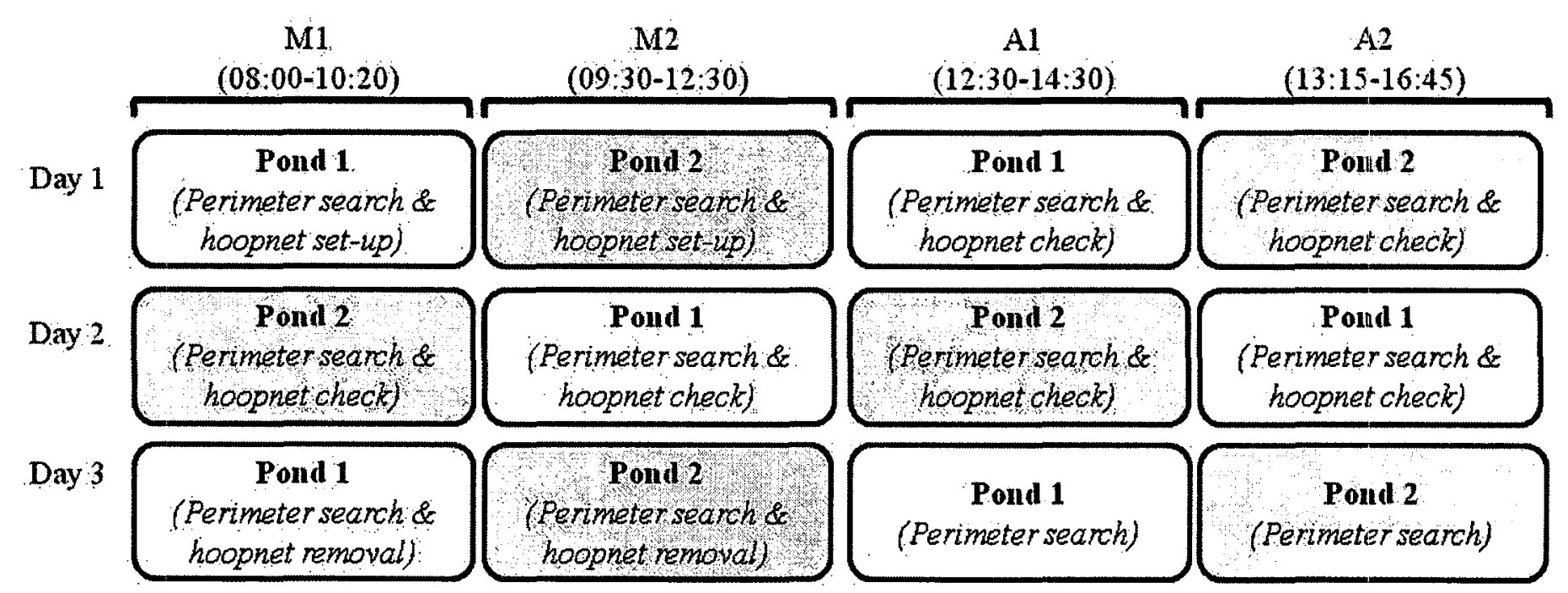

(Approximately 6 weeks passes between sampling Day 3 and Day 4)

\begin{tabular}{|c|c|c|c|c|}
\hline Day 4 & $\begin{array}{c}\text { Pond } 2 \\
\text { (Penmetersearch \& } \\
\text { hoopnet set } u p)\end{array}$ & $\begin{array}{c}\text { Pond } 1 \\
\text { (Perimeter search \& } \\
\text { hoopnet set-up) }\end{array}$ & $\begin{array}{c}\text { Pond } 2 \\
\text { (Penmeter search \& } \\
\text { hoopnet cheak) }\end{array}$ & $\begin{array}{c}\text { Pond 1 } \\
\text { (Perimeter search \& } \\
\text { hoopnet check) }\end{array}$ \\
\hline Day 5 & $\begin{array}{c}\text { Pould i } \\
\text { (Perimeter search \& } \\
\text { hoopnet check) }\end{array}$ & $\begin{array}{l}\text { Pomd } 2 \\
\text { (Perimetersearch } \& \\
\text { hoopnet cheal) }\end{array}$ & $\begin{array}{c}\text { Pond 1 } \\
\text { (Penimeter search \& } \\
\text { hoopnet check) }\end{array}$ & $\begin{array}{c}\text { Pond } 2 \\
\text { (Perimeter search \& } \\
\text { hoopnet check) }\end{array}$ \\
\hline Day 6 & $\begin{array}{c}\text { Pond } 2 \\
\text { (Perimeter search \& } \\
\text { hoopnet removal) }\end{array}$ & $\begin{array}{c}\text { Pond 1 } \\
\text { (Perimeter search \& } \\
\text { hoopnet removal) }\end{array}$ & $\begin{array}{c}\text { Pond } 2 \\
\text { (Penmeter search) }\end{array}$ & $\begin{array}{c}\text { Pond 1 } \\
\text { (Perimetersearch) }\end{array}$ \\
\hline
\end{tabular}

Figure 2. Summary of the sampling protocol. Ponds were paired (pond $1=$ white box, pond $2=$ grey box) and sampled twice daily for 3 consecutive days twice during the summer (totalling 6 sampling days at each pond). Sampling days were divided into 4 periods: Morning 1 (M1), Morning 2 (M2), Afternoon 1 (A1) and Afternoon 2 (A2) such that each of the ponds within a sampling pair was visited once in the morning and once in the afternoon each sampling day. The order of visits alternated each day. 


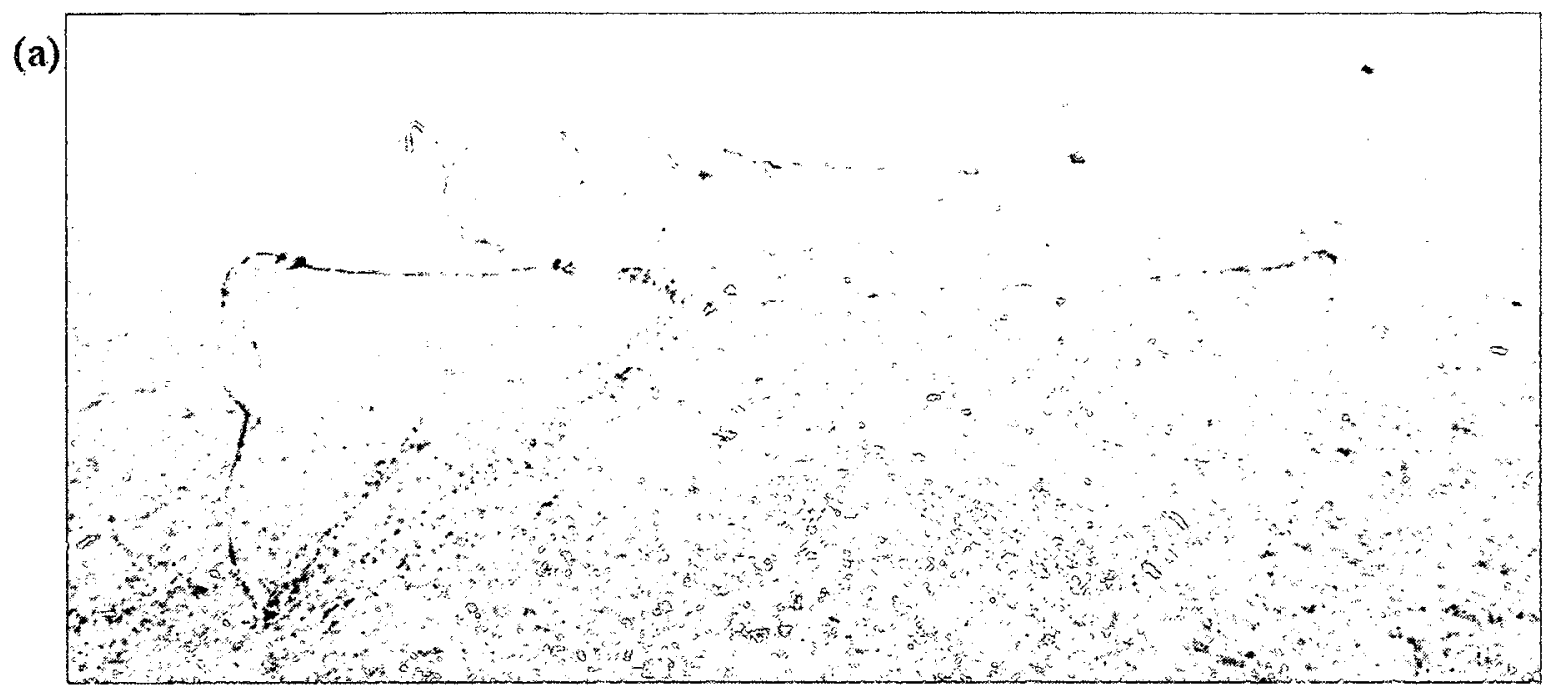

(b)

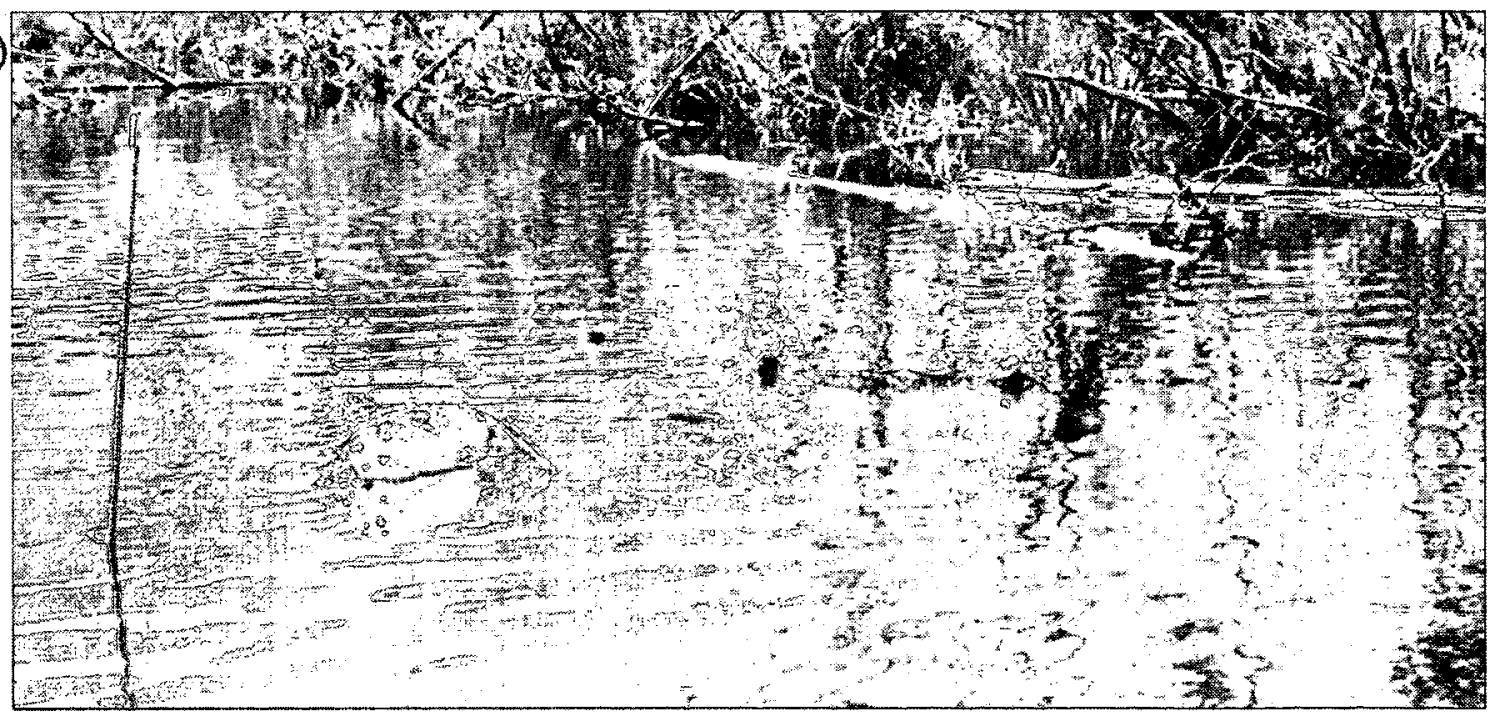

Figure 3. Example of one of the hoopnets used during the study. (a) shows, on land, how a hoopnet is set up once it is in the water; (b) shows a hoopnet set up at a pond with an added floatation device to allow trapped turtles constant access to the surface for air. Two hoopnets $(61 \mathrm{~cm}$ diameter, $183 \times 91 \mathrm{~cm}$ wings, $3.8 \mathrm{~cm}$ square nylon netting) were installed at each site with the open end facing shore. Nets were baited with sardines and left in place for the duration of each three consecutive day period. 


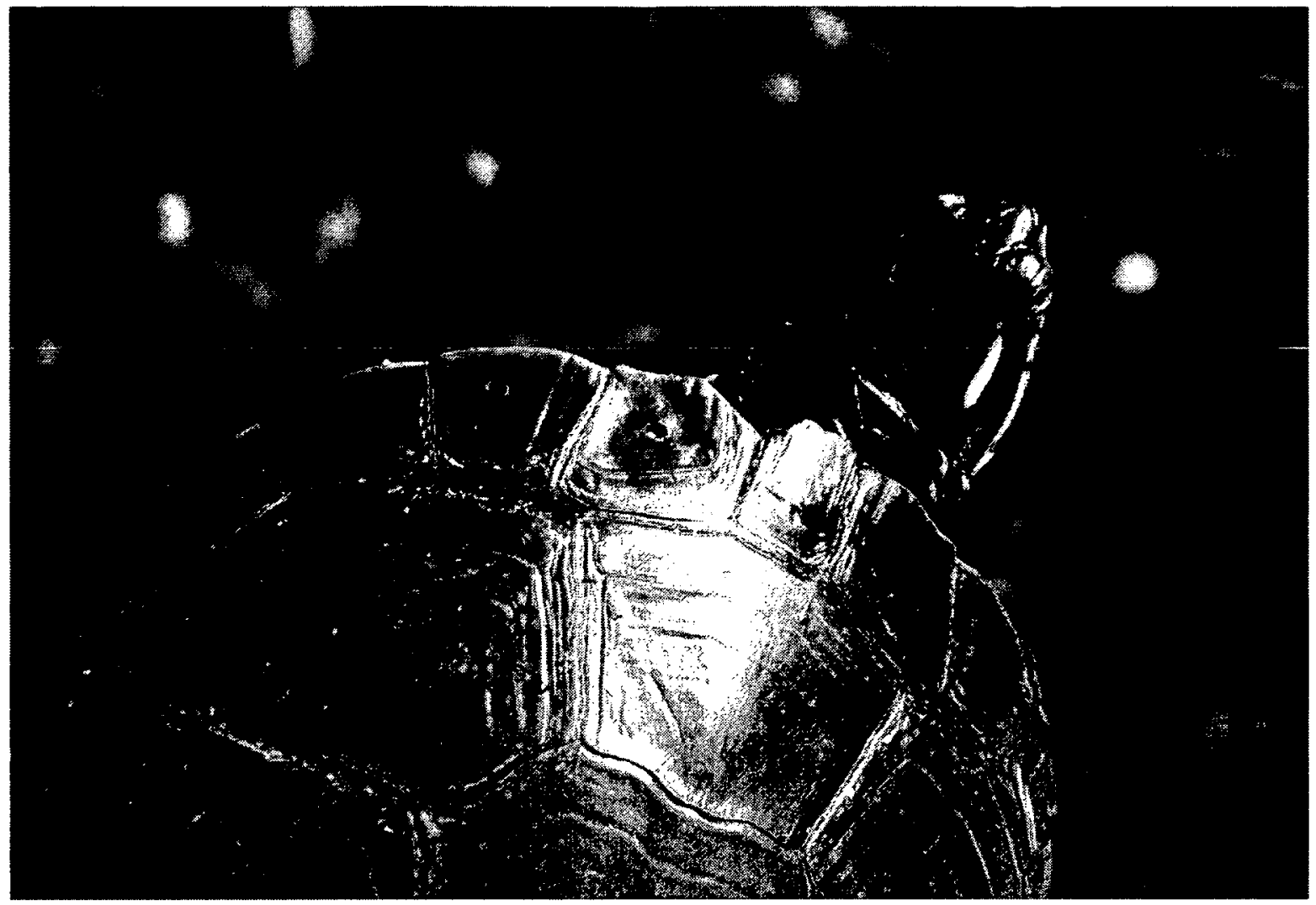

Figure 4. One of the permanent unique marks given to each turtle that was captured. Marks were made by drilling a small hole in the outer edge of two marginal scutes. 


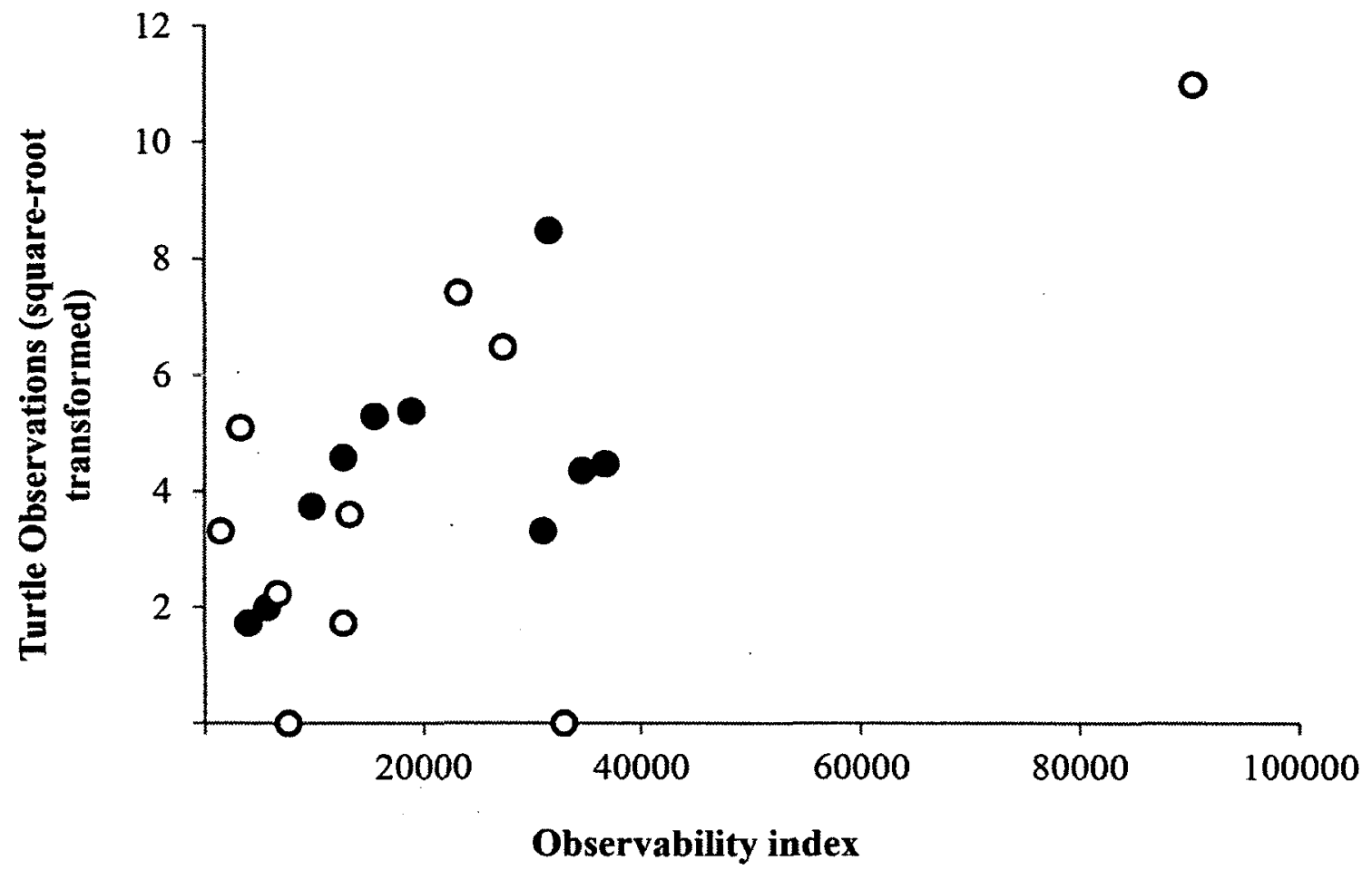

Figure 5. The number of Turtle Observations (square root transformed) at Road (•) and No $\operatorname{Road}(\mathrm{O})$ sites plotted against Observability index. 


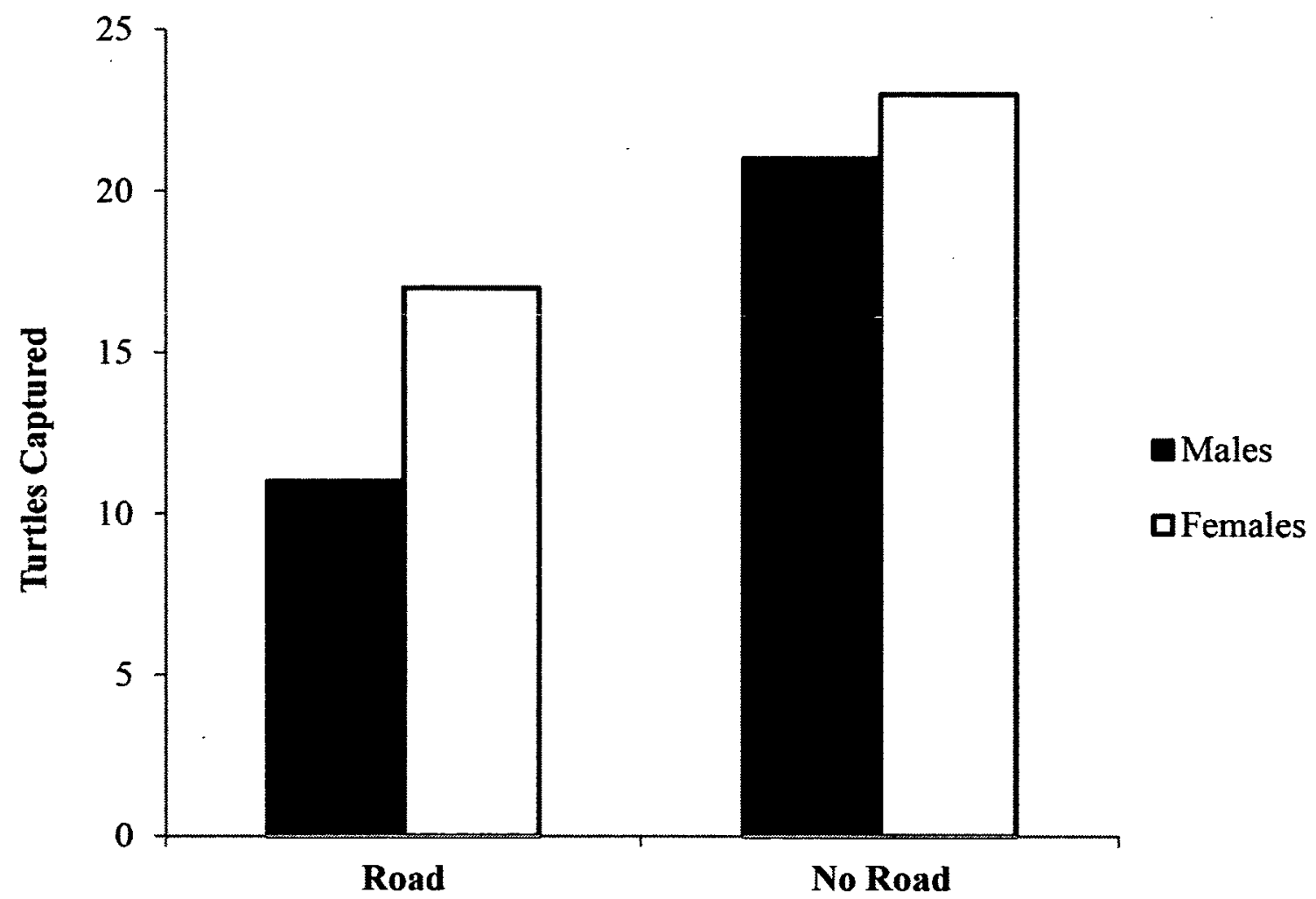

Figure 6. The number of male and female turtles captured at Road and No Road sites. 

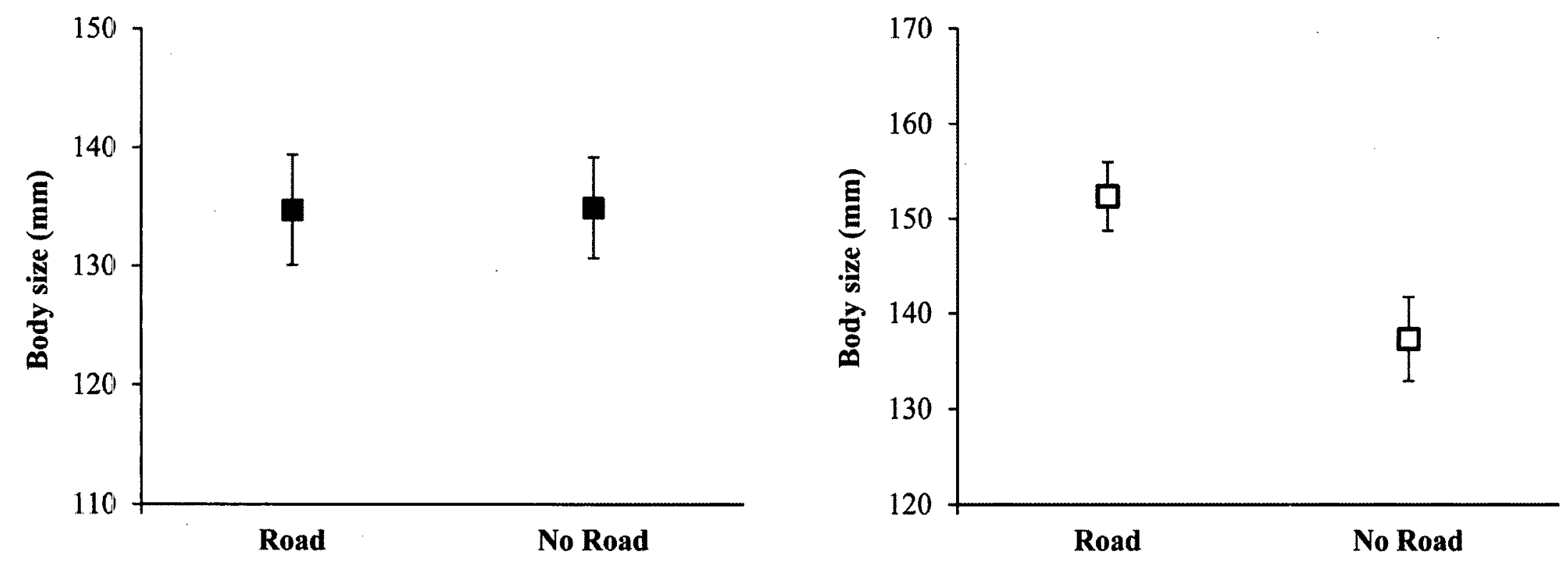

Figure \%. Mean body size of captured males ( $\square$ ) and females ( $\square$ ), measured as straight line carapace length in mm, across Road and No Road sites. 
Appendix A. The number of turtle observations made between June $1^{\text {st }}$ and August $28^{\text {th }}, 2011$. "Turtle Observations" include all observations that were affected by observability (turtle sightings and turtles captured by dipnet or by hand). "Maximum Basking Observations" is the highest number of turtle Basking Observations made during a single visit. "In-water Observations" include all observations made while turtles were swimming in the water.

\begin{tabular}{|c|c|c|c|}
\hline Site & Turtle Observations & Maximum Basking Observations & In-water Observations \\
\hline $\mathrm{R} 1$ & 4 & 1 & 3 \\
\hline $\mathrm{R} 2$ & 21 & 4 & 2 \\
\hline R3 & 72 & 6 & 38 \\
\hline R4 & 14 & 1 & 9 \\
\hline R5 & 19 & 5 & 3 \\
\hline R6 & 3 & 1 & 2 \\
\hline R7 & 28 & 3 & 13 \\
\hline $\mathrm{R} 8$ & 29 & 3 & 17 \\
\hline R9 & 20 & 5 & 4 \\
\hline R10 & 11 & 2 & 7 \\
\hline Total & 221 & 31 & 98 \\
\hline NR1 & 121 & 24 & 14 \\
\hline NR2 & 55 & 5 & 38 \\
\hline NR3 & 11 & 5 & 0 \\
\hline NR4 & 3 & 0 & 3 \\
\hline NR5 & 0 & 0 & 0 \\
\hline NR6 & 13 & 6 & 2 \\
\hline NR7 & 42 & 13 & 19 \\
\hline NR8 & 5 & 3 & 1 \\
\hline NR9 & 26 & 5 & 8 \\
\hline NR10 & 0 & 0 & 0 \\
\hline Total & 276 & 61 & 85 \\
\hline
\end{tabular}


Appendix B Turtles captured by dipnet or hoopnet between June $1^{\text {st }}$ and August $28^{\text {th }}, 2011$. Sex was determined using secondary sex characteristics: the male cloacal opening extends past the posterior edge of the carapace while the female's does not. Males also have much longer foreclaws. I used the carapace length of the smallest identifiable male I sampled as the minimum size for assigning sex.

\begin{tabular}{|c|c|c|c|c|c|c|c|c|c|c|c|c|}
\hline \multirow{2}{*}{ Site } & \multicolumn{3}{|c|}{ Turtles Captured } & \multicolumn{3}{|c|}{ Females } & \multicolumn{3}{|c|}{ Males } & \multicolumn{3}{|c|}{ Juveniles } \\
\hline & Total & Dipnet & Hoopnet & Total & Dipnet & Hoopnet & Total & Dipnet & Hoopnet & Total & Dipnet & Hoopnet \\
\hline Rl & 3 & 0 & 3 & 2 & 0 & 2 & 1 & 0 & 1 & 0 & 0 & 0 \\
\hline $\mathrm{R} 2$ & 4 & 0 & 4 & 3 & 0 & 3 & 1 & 0 & 1 & 0 & 0 & 0 \\
\hline R3 & 5 & 3 & 2 & 3 & 2 & 1 & 1 & 0 & 1 & 1 & 1 & 0 \\
\hline R4 & 2 & 0 & 2 & 1 & 0 & 1 & 0 & 0 & 0 & 1 & 0 & 1 \\
\hline R5 & 4 & 0 & 4 & 1 & 0 & 1 & 3 & 0 & 3 & 0 & 0 & 0 \\
\hline R6 & 1 & 0 & 1 & 1 & 0 & 1 & 0 & 0 & 0 & 0 & 0 & 0 \\
\hline $\mathrm{R} 7$ & 7 & 2 & 5 & 3 & 2 & 1 & 4 & 0 & 4 & 0 & 0 & 0 \\
\hline R8 & 2 & 0 & 2 & 2 & 0 & 2 & 0 & 0 & 0 & 0 & 0 & 0 \\
\hline R9 & 2 & 0 & 2 & 1 & 0 & 1 & 1 & 0 & 1 & 0 & 0 & 0 \\
\hline $\mathrm{R} 10$ & 0 & 0 & 0 & 0 & 0 & 0 & 0 & 0 & 0 & 0 & 0 & 0 \\
\hline Total & 30 & 5 & 25 & 17 & 4 & 13 & 11 & 0 & 11 & 2 & 1 & 1 \\
\hline NR1 & 18 & 8 & 10 & 11 & 7 & 4 & 5 & 0 & 5 & 2 & 1 & 1 \\
\hline NR2 & 7 & 0 & 7 & 2 & 1 & 1 & 5 & 0 & 5 & 0 & 0 & 0 \\
\hline NR3 & 6 & 0 & 6 & 2 & 0 & 2 & 4 & 0 & 4 & 0 & 0 & 0 \\
\hline NR4 & 4 & 0 & 4 & 3 & 0 & 3 & 1 & 0 & 1 & 0 & 0 & 0 \\
\hline NR5 & 0 & 0 & 0 & 0 & 0 & 0 & 0 & 0 & 0 & 0 & 0 & 0 \\
\hline NR6 & 2 & 0 & 2 & 2 & 0 & 2 & 0 & 0 & 0 & 0 & 0 & 0 \\
\hline NR7 & 2 & 1 & 1 & 1 & 1 & 0 & 1 & 0 & 1 & 0 & 0 & 0 \\
\hline NR8 & 0 & 0 & 0 & 0 & 0 & 0 & 0 & 0 & 0 & 0 & 0 & 0 \\
\hline NR9 & 7 & 5 & 2 & 2 & 2 & 0 & 5 & 3 & 2 & 0 & 0 & 0 \\
\hline NR10 & 0 & 0 & 0 & 0 & 0 & 0 & 0 & 0 & 0 & 0 & 0 & 0 \\
\hline Total & 46 & 14 & 32 & 23 & 11 & 12 & 21 & 3 & 18 & 2 & 1 & 1 \\
\hline
\end{tabular}


Appendix C. Summary of the local variables estimated at each site. Percent area covered by forest, grass, shrub and open ground (such as dirt or gravel) were estimated within a $5 \mathrm{~m}$ radius of the pond edge. Percent cover by openwater, emergent vegetation and submerged vegetation were all estimated at the pond surface. $\mathrm{pH}$, temperature and conductivity were measured at the pond surface.

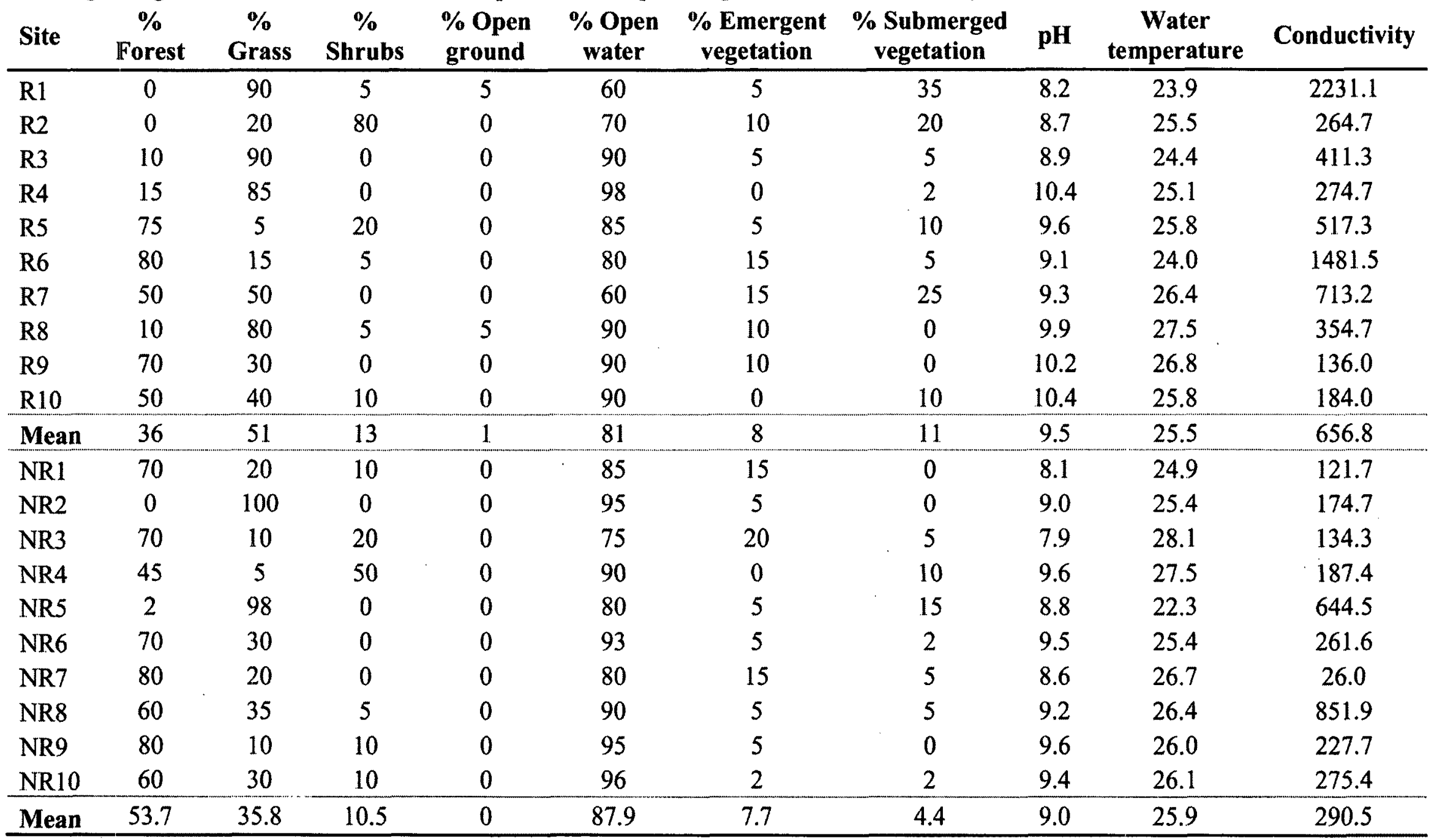


Appendix D. Results of four multiple linear regressions using square root transformed Maximum Basking Observations as the response variable and (b) pond size with site type (Road vs. No Road, where $\operatorname{Road}=1$ and No $\operatorname{Road}=0)$, $(c)$ pond size with road density $\left(\mathrm{m} / \mathrm{km}^{2}\right)$ and (d) pond size with total traffic volume (total AADT) as predictor variables.

\begin{tabular}{llccccc}
\hline & Predictor variable & $\mathbf{R}^{2}$ & df & F & B & p \\
\hline (a) & Pond size & 0.126 & 1,18 & 2.586 & 0.354 & 0.125 \\
(b) Site type & 0.013 & 1,18 & 0.232 & -0.113 & 0.636 \\
(c) Road density & 0.052 & 1,18 & 0.993 & -0.229 & 0.332 \\
(d) Total AADT & 0.034 & 1,18 & 0.624 & -0.183 & 0.440 \\
\hline
\end{tabular}

Appendix E. Results of four simple linear regressions using square root-transformed Maximum Observations as the response variable and (a) pond size (perimeter in $\mathrm{m}$ ), (b) site type (Road vs. No Road, where Road $=1$ and No Road $=0),(\mathrm{c}) \mathrm{road}$ density $\left(\mathrm{m} / \mathrm{km}{ }^{2}\right)$ and (d) total traffic volume (total AADT) as predictor variables.

\begin{tabular}{|c|c|c|c|c|c|c|}
\hline & Predictor variable & $\mathbf{R}^{2}$ & df & $\mathbf{F}$ & $\beta$ & $\mathbf{p}$ \\
\hline (a) & Observability index & 0.116 & 1,18 & 2.367 & 0.341 & 0.141 \\
\hline (b) & Site type & 0.035 & 1,18 & 0.647 & 0.186 & 0.432 \\
\hline (c) & Road density & $<0.001$ & 1,18 & $<0.001$ & 0.005 & 0.984 \\
\hline (d) & Total AADT & $<0.001$ & 1,18 & $<0.001$ & 0.005 & 0.984 \\
\hline
\end{tabular}

